http://dx.doi.org/10.11646/zootaxa.4018.1.3

http://zoobank.org/urn:lsid:zoobank.org:pub:1D7114C5-225C-403E-9F08-F28B5E1E6571

\title{
Revision of the Bicyclus ignobilis species-group (Lepidoptera: Nymphalidae: Satyrinae) with descriptions of two new species
}

\author{
OSKAR BRATTSTRÖM ${ }^{1}$, KWAKU ADUSE-POKU ${ }^{1}$, STEVE C. COLLINS ${ }^{2} \&$ PAUL M. BRAKEFIELD ${ }^{1}$ \\ ${ }^{1}$ University Museum of Zoology, Cambridge University, Cambridge, UK. \\ e-mail:oskar.brattstrom@gmail.com; kadusepoku@yahoo.com;pb499@cam.ac.uk \\ ${ }_{2}^{2}$ African Butterfly Research Institute, Nairobi, Kenya.e-mail: collinsabri@gmail.com
}

\begin{abstract}
The ignobilis-group of the genus Bicyclus Kirby 1871 is revised. The species-group contains six species with a distinct wing pattern, but limited intraspecific variation, distributed across tropical African rainforest. We investigate a set of more than 1000 specimens from a range of museum collections, including some type material, and thoroughly update the biogeographical knowledge for the group. We also describe two new species as members of the group. The included species are: Bicyclus ignobilis (Butler 1870) stat. rev., B. rileyi Condamin 1961, B. maesseni Condamin 1971, B. brakefieldi Brattström 2012, B. ottossoni sp. nov. and B. vandeweghei sp. nov. Due to observing a gradual morphological cline within $B$. ignobilis without any sharp transitions we suppress the previously identified subspecies $B$. ignobilis eurini Condamin \& Fox 1963 syn. nov. and B. ignobilis acutus Condamin 1965 syn. nov.
\end{abstract}

Key words: Nymphalidae, Bicyclus ignobilis-group, Bicyclus ottossoni sp. nov., Bicyclus vandeweghei sp. nov.

\section{Introduction}

The genus Bicyclus Kirby 1871 includes more than 85 described species distributed across sub-Saharan Africa (Condamin 1973). A single taxon, Bicyclus anynana socotrana (Butler), is endemic on the island of Socotra which is part of Asia (Yemen), but biogeographically lies inside the Afrotropical Region. Bicyclus is by far the most species-rich African genus of Satyrinae, but because of their often cryptic colour patterns they are frequently misidentified in nature as well as in collections. The marked intraspecific variation within the genus has also led to a high number of invalid names given to seasonal morphs of many species. As part of a larger project studying evolutionary patterns across the whole subtribe Mycalesina Reuter 1896 we are now gradually revising all of Bicyclus, and this paper forms a part of the systematic contributions from that work.

The ignobilis-group was designated as a species-group by Condamin (1973) when revising the genus Bicyclus. He grouped the then three included species together due to their highly irregular disposition of the ventral hindwing eyespots and discal band, and because of shared characters in the male genitalia. Before Condamin's early work on Bicyclus only a single taxon was known from this group, namely B. ignobilis (Butler 1870). This species was initially described from female material (most likely a single specimen) collected in Ghana. It was not until almost a century later that additional species were described within the current ignobilis-group. Condamin described $B$. rileyi Condamin 1961 and $B$. maesseni Condamin 1971. He was also responsible for the designation of two subspecies B. ignobilis eurini Condamin \& Fox 1963 syn. nov. and B. ignobilis acutus Condamin 1965 b syn. nov. The latest species to be described within the ignobilis-group was B. brakefieldi Brattström 2012.

During our work in the field and across a range of museum collections - with the aim of cataloguing various traits across the whole genus Bicyclus for use in comparative studies of evolutionary patterns - we came across two morphologically distinct and undescribed species in the ignobilis-group. We also found a range of new geographical records for the species-group. This paper, therefore, aims to summarise the current taxonomic status and known distribution of the complete ignobilis-group, as well as to describe two new species: B. ottossoni sp. nov. and $B$. vandeweghei sp. nov. 


\section{Material \& Methods}

Acquisition of samples and original literature. Most of the examined voucher specimens used in this study are stored at the African Butterfly Research Institute (ABRI) in Nairobi, Kenya. The ABRI collections have numerous specimens from almost every part of sub-Saharan Africa, which help to facilitate studies of biogeography and clinal morphological variation. We also investigated specimens from the Musée Royal de l'Afrique Central (MRAC) in Tervuren, Belgium. This contributed a number of records from central parts of the Democratic Republic of Congo, an area not well represented in any other major collection, including ABRI. Other collections were mainly consulted to study types and to quickly check that there were no suspected new species in need of closer investigation. Because no obvious new informative records were found in these collections we limited the work on non-type material from the ignobilis-group to material from ABRI and MRAC. A list of all collections visited (or mentioned in the text) is presented in Table 1. Some specimens, including the holotype of B. ottossoni sp. nov., were collected during fieldwork for other projects (e.g. Bacquet, Brattström et al. 2015). We did not use distributional records from older literature, except those from Condamin (1971) from the Western parts of the range, as the recent additions of several morphologically similar taxa to the species-group occurring from Nigeria and eastwards (Brattström 2012; the new species described below) make it impossible to say with certainty what species older records referred to.

TABLE 1. List of abbreviations for museum collections visited throughout the course of this study (or known to have material that was indirectly studied through photographs in publications). The second section is listing collections for which only limited material was available for the ignobilis-group and those collections were not studied further for this current revision.

\begin{tabular}{ll}
\hline Acronym & Full name, City, Country \\
\hline ABRI & African Butterfly Research Institute, Nairobi, Kenya \\
BMNH & Natural History Museum, London, United Kingdom \\
MNHN & Muséum National d'Histoire Naturelle, Paris, France (Not visited) \\
MRAC & Musée royal de l'Afrique central, Tervuren, Belgium \\
MZUJ & Zoological Museum of the Jagiellonian University, Kraków, Poland (Not visited) \\
NHMW & Naturalhistorische Museum, Vienna, Austria \\
NHRS & Swedish Museum of Natural History, Stockholm, Sweden \\
OBRES & Oskar Brattström's Research Collection, Cambridge, United Kingdom \\
& \\
MNHB & Museum für Naturkunde, Humboldt-Universität, Berlin, Germany \\
OUMNH & Oxford University Museum of Natural History, Oxford, United Kingdom \\
PCM & Powell-Cotton Museum, Quex Park, United Kingdom \\
SMNS & Stuttgart State Museum of Natural History, Stuttgart, Germany \\
UMZC & University Museum of Zoology, Cambridge, United Kingdom \\
ZFMK & Zoological Research Museum Alexander Koenig, Bonn, Germany \\
\hline
\end{tabular}

All illustrated specimens were photographed using a Nikon D300 and an AF-S Micro NIKKOR 60mm f/2.8G ED lens set at a fixed focus distance and with all exposure settings (including flash output) fully locked. Lighting was provided using a Metz Ring Flash 15 MS-1, and colours were balanced using a QP Card 201 together with the calibration software QPcolorsoft 501 v. 2.0.1. The RAW images were developed and edited using Adobe Photoshop CS5. The editing process involved removal of background, sharpening, and aligning specimens. All operations were carried out using a standardised custom action set to ensure that images were comparable with regard to colour and size. The ventral images of all specimens have been mirror imaged for easier comparison with the corresponding dorsal images. The enlarged images of androconial structures have been lightened to enable darker structures mentioned in the text to be seen clearly. In these images, small edits have also been made to remove dust and damaged sections of the wings in cases where they draw attention away from the androconial details (actual androconial structures were not edited). The copyrights of all the voucher images belong to the respective museums and their trustees. 


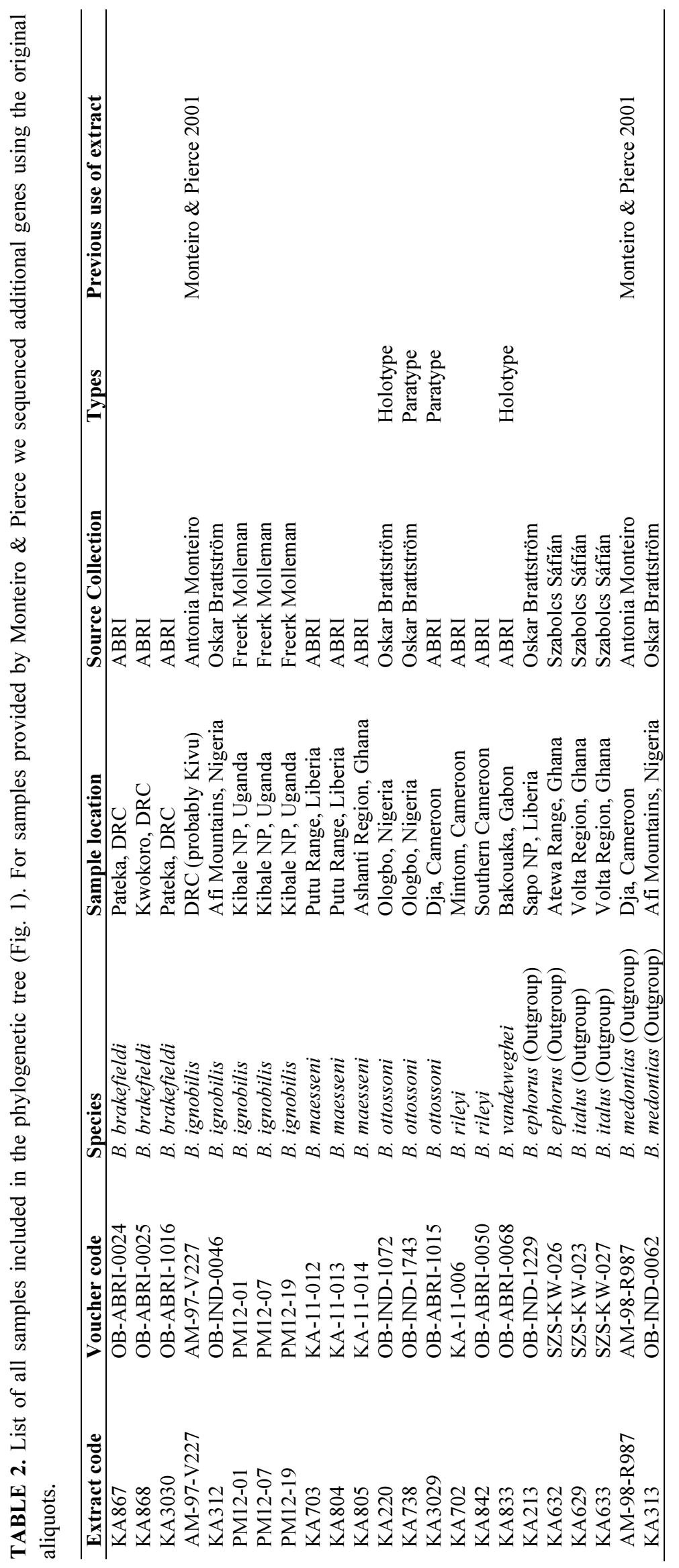


Genitalia dissections. The abdominal tips of at least one male per species were dissected to inspect the genitalia characters. The abdominal tissues were softened with heated $10 \% \mathrm{KOH}$ solution and then cleaned using a pair of micro forceps. Images of the dissected genitalia were taken using focus-stacking software and the resulting montages were later cleaned up in Adobe Photoshop CS5, only neutralising the background and balancing the contrast across samples. The structures themselves were not edited, except to remove dust and scales.

Molecular phylogeny construction. A total of 17 exemplar taxa representing the four previously described species in the ignobilis-group, as well as the two taxa being described as new species in this paper, constituted the in-group (Table. 2). The tree was rooted using six exemplar taxa from three species, Bicyclus ephorus Weymer, $B$. italus (Hewitson) and B. medontias (Hewitson). These species are part of a sister clade to the ignobilis-group as documented in a recent phylogenetic study of the whole subtribe Mycalesina, of which Bicyclus is a member (Aduse-Poku et al. 2015). Samples were collected either by the authors during field expeditions between 2008 and 2014, or obtained through colleagues collecting material in Africa. The remaining samples were taken from the collections of ABRI. Genomic DNA was extracted from two legs per specimen using the Qiagen DNEasy extraction kit. Nine molecular markers; one mitochondrial (cytochrome c oxidase subunit I, CO1) and eight nuclear (Ribosomal Protein S5, RpS5; Ribosomal Protein S2, RpS2; wingless, wg1; glyceraldhyde-3-phosphate dehydrogenase, GAPDH; Elongation factor 1 alpha, EF-1 $\alpha$; Cytosolic malate dehydrogenase, MDH; Carbamoyl phosphate synthase domain protein, CAD; and Arginine Kinase, ArgKin) gene regions were amplified and sequenced for each of the exemplar taxa using primer-pairs obtained from Wahlberg \& Wheat (2008). Successful amplicons were cleaned with EXO-SAPIT and sent to Macrogen Services in Amsterdam for nucleotide sequencing. The resultant nucleotide sequences were aligned by eye using Bioedit (Hall 1999). DNA sequences of 2 genes (CO1, EF-1 $\alpha$ ) and aliquots of extracts from two specimens used in a previous Bicyclus phylogenetic study (Monteiro \& Pierce 2001) were obtained from the authors and used in the present study with additional genes sequenced from the aliquots.

The phylogenetic analyses were first carried out separately for each gene, producing gene trees, and later for all of the nine genes concatenated, but partitioned by gene. Tree topologies were estimated using Maximum likelihood and Bayesian Inference methods, implemented in RaxML (Stamatakis 2006) and BEAST (Drummond \& Rambaut 2007) programs respectively.

Collection of distributional data. Location data was recorded from the labels of all investigated specimens. In general we did not note the exact collection date as it is of no importance to this study, especially as the speciesgroup shows no clear seasonal plasticity (Brakefield \& Frankino 2009). Some of the older material had deficient location descriptions and they are therefore of little use, often including only country of origin or referring to a larger geographic area. Such records were not used as we always had access to better defined records from within the same broad area. We tried to locate the exact geographic position for all defined locations using a combination of notes from ABRI collectors, digital location databases provided by MRAC and Michel Libert, The PerryCastañeda Library Map Collection (http://www.lib.utexas.edu/maps/africa.html), and also from basic web searches. The locations were used to produce the distribution maps and are all presented in Supplementary Table 1, given to the closest possible degrees and minutes lat/long. Locality names have generally been updated to their currently official names in those cases where old colonial names have been replaced in the post-independence era. In the following text, we refer to The Democratic Republic of Congo as DRC.

Taxonomic nomenclature and considerations. All references to wing venation follow the simplified 'English', or numerical system (Miller 1970) with the exception that we call the merged hindwing space 1/1c as space 1c. Also, hindwing vein 1 is called vein 1b. The same system was used by Larsen (2005). The reported lengths of forewings of newly described species are measured from the base of the wing up to the distal end of vein 7.

\section{Results and discussion}

Investigated material. In total we investigated 1021 specimens from all of the six species in the ignobilis-group. There is a clear bias in collections towards more female specimens for the two more common species (B. ignobilis and B. maesseni) (Table 3). A more detailed listing of all investigated specimens together with collection localities is found in Supplementary Table 1. 
Phylogenetic reconstruction. The molecular phylogeny recovers all six species forming the ignobilis-group as separate units, and all but two (B. brakefieldi and B. vandeweghei sp. nov.) show a long separate evolutionary history from their closest relatives (Fig. 1). The ignobilis-group split from their closest common ancestor about 17 million years ago (Aduse-Poku et al. 2015) and their sister group is a distinct clade containing a set of large and highly distinct species of Bicyclus, generally having iridescent blue apical bands on their forewings. Morphologically this clade is very different to the ignobilis-group, which is instead more similar to the basal evadne-group, especially $B$. rileyi, the most basal ignobilis-group member. The wing pattern of $B$. rileyi is largely similar to the species in the evadne-group, however both the androconial structures and genitalia are markedly different between the species-groups. Condamin (1973) placed the evadne and ignobilis-groups as sisters in his morphological phylogeny, with the nobilis-group as a closely related out-group. In the first molecular phylogeny of Bicyclus the nobilis-group was not included and the position of the ignobilis-group was not well supported (Monteiro \& Pierce 2001). Recent studies have shown that the nobilis-group is sister-group to the morphologically very different sciathis-group (Aduse-Poke et al. 2015).

The phylogenetic analysis also helped us to verify the morphology of females from $B$. ottossoni and $B$. brakefieldi, but unfortunately the only known specimen believed to be the female of $B$. vandeweghei (described as paratype on morphological grounds) was not successfully sequenced. Given that we know only of a single pair of individuals of this new species more samples would be valuable to verify that the female paratype is definitely correctly assigned. Whilst the genetic variation between the samples of $B$. ignobilis is quite substantial we have not sampled molecular data for this species in a systematic way across its distribution, and combined with finding a gradual morphological cline blending the described subspecies (see species section), we do not feel it is justified to continue to treat them as separate entities (see separate species section for details).

TABLE 3. Number of specimens investigated per species. For full details of locations and depository see Supplementary Table 1.

\begin{tabular}{|c|c|c|c|c|}
\hline Species & Males & Females & Total & Comments \\
\hline B. ignobilis & 276 & 460 & 736 & $\begin{array}{l}\text { Only studied in detail at } \\
\text { ABRI and MRAC }\end{array}$ \\
\hline B. rileyi & 25 & 12 & 36 & $\begin{array}{l}\text { All known material studied } \\
\text { and listed }\end{array}$ \\
\hline B. maesseni & 79 & 127 & 206 & $\begin{array}{l}\text { Only studied in detail at } \\
\text { ABRI and MRAC }\end{array}$ \\
\hline B. brakefieldi & 17 & 5 & 22 & $\begin{array}{l}\text { All known material studied } \\
\text { and listed }\end{array}$ \\
\hline B. ottossoni & 8 & 10 & 18 & $\begin{array}{l}\text { All known material studied } \\
\text { and listed }\end{array}$ \\
\hline B. vandeweghei & 1 & 1 & 2 & $\begin{array}{l}\text { All known material studied } \\
\text { and listed }\end{array}$ \\
\hline TOTAL & 406 & 615 & 1021 & \\
\hline
\end{tabular}

Genitalia morphology. The male genitalia show very little differentiation within the ignobilis-group (Figs. 5, 9, 13, 17, 21, 25). Previously it was assumed that genitalia had limited diagnostic value in Bicyclus, apart from assigning species to broader morphological species-groups (Condamin 1973). However, with modern technology enabling a more effective documentation of genitalia and a rapid comparison of multiple images it is clear that sometimes differences are distinctive and consistent, even if on a very small scale. In addition, being able to verify the potential significance of even subtle differences between suspected separate taxa with molecular data, it is now clear that sometimes these differences are highly useful tools for identification (e.g. Brattström et al. unpublished data). However, in the ignobilis-group the genital morphology is almost identical between species and there are, at most, only minor differences, mainly in the shape of the tip of the valves. Based on finding no differences of a magnitude likely to be of any ecological significance in the males, we did not investigate the genitalia of the females. Condamin (1973) illustrated the female genitalia morphology for almost all Bicyclus species and he felt they generally had no diagnostic value. He also directly compared the female genitalia of B. ignobilis and B. maesseni (Condamin 1971) and 
found no differences. Were it not for the androconial differences and the molecular data we would not have felt confident in identifying any species in the species-group using genitalia characters alone, nor do we consider them of high diagnostic value compared to other traits. Given the long divergence time between most species in the group, and of the species-group as a whole, it is likely that no strong divergent selection has occurred in relation to genitalia morphology within the ignobilis-group after their initial divergence from other Bicyclus.

Androconial characters. Investigating the androconial structures across the members of the ignobilis-group shows that, despite some variation between individuals of the same species (likely due to natural wing wear of older individuals), the presence or absence of even small androconial structures, such as the hair pencil found in space $1 \mathrm{~b}$ on the dorsal forewing of some species (Figs. 10, 14, 22, 26), are reliable cues for identification. One character that was not mentioned by Condamin (1973) is the total lack of any ventral forewing androconial structures along vein 1, in contrast to the situation found in most other Bicyclus species. The ignobilis-group is the only currently used species group completely lacking this type of androconial character in all of its members.

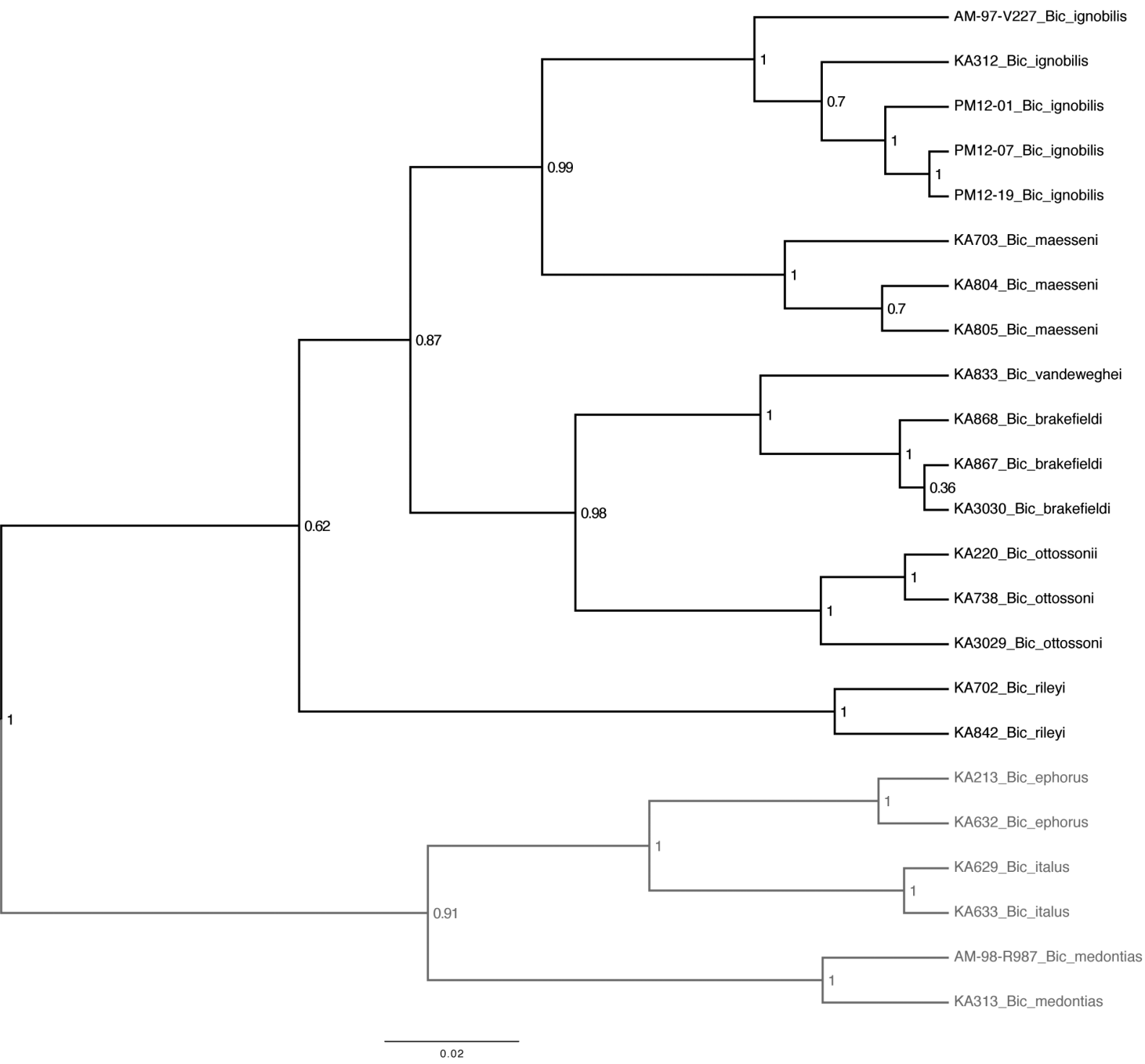

FIGURE 1. Phylogenetic tree of the Bicyclus ignobilis species-group constructed from Bayesian analysis carried out in BEAST. Node labels show the posterior probability for each node. All the species are recovered as separate units. The split from the outgroup (shown in grey) occurred about 17 million years ago (see main text). The genetic differences between most species in the ignobilis-group are surprisingly large given that the morphological differences within the group are very small when compared to most other Bicyclus species-groups of a similar evolutionary age. The female morphology of B. brakefieldi (KA3030) and B. ottossoni (KA3029) are verified by the phylogeny. 
Bicyclus ignobilis (Butler 1870)
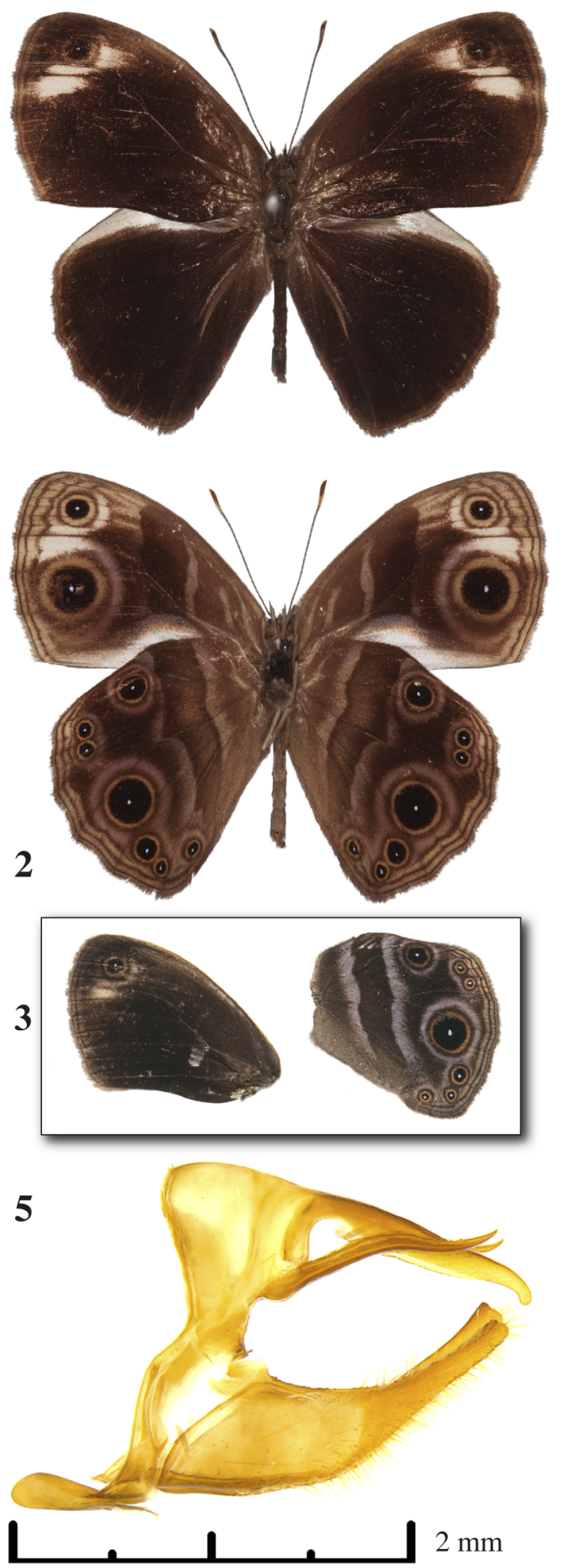

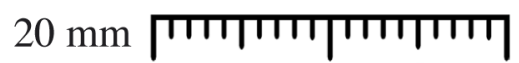
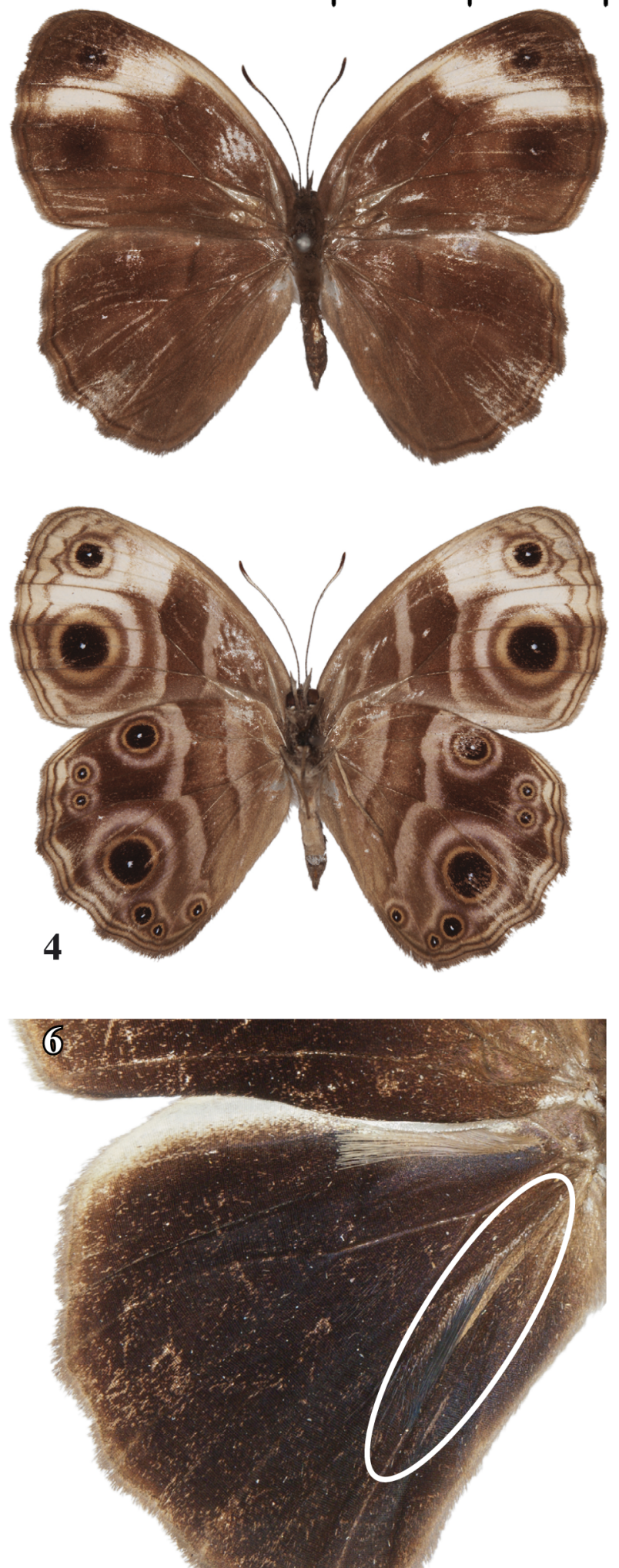

FIGURES 2-6. Bicyclus ignobilis (Butler 1870). 2. Male, DRC (OB-VIE-0046) 3. Dorsal forewing and ventral hindwing showing the main morphological differences in the western populations. The shown specimen (OB-IND-0046) is from eastern Nigeria. A female from the western region is shown in Fig. 32. 4. Female, DRC (OB-VIE-0047). 5. Male genitalia, Uganda (OB-ABRI-0092). 6. Androconial structures (OB-ABRI-0092). There is a comb of black hairs (encircled in white) covering an enlarged section of vein $1 \mathrm{~b}$ on the dorsal hindwing. The cell-brush is clearly visible in the image and there are no forewing androconial structures. 


\section{Chronological listing of currently recognised species}

\section{Bicyclus ignobilis Butler stat. rev.}

(Figs. 2-6, 27-28, 32-33)

Mycalesis ignobilis Butler 1870 (Gold Coast $=$ Ghana)

Bicyclus ignobilis eurini Condamin \& Fox 1963 (Lolodorf, Cameroon) syn. nov.

Bicyclus ignobilis acutus Condamin 1965b (Bwamba Forest, Uganda) syn. nov.

Material examined. Type material: Holotype (ignobilis) $q$ : Gold Coast (Ghana), No further data, BMNH(E) \#1054538 (BMNH). Holotype (acutus) ô $^{\top}$ Uganda, Buamba Forest ( $\left.0^{\circ} 49^{\prime} \mathrm{N}, 30^{\circ} 04^{\prime} \mathrm{E}\right)$, Sem[u]liki Valley, 2,3002,800 ft., 3-7.xi.1911, S.A. Neave leg., No. Rh. 18232 (BMNH). Allotype (acutus) $q$ : Uganda, Budongo Forest $\left(1^{\circ} 45^{\prime} \mathrm{N}, 31^{\circ} 25^{\prime} \mathrm{E}\right)$, Unyoro, 3,400 ft., 11-15.xii.1911, S.A. Neave leg., No. Rh. 18233 (BMNH).

Non-type material. 276 o \& 453 . . See Supplementary Table 1.

Diagnosis. Both sexes of $B$. ignobilis usually lack an eyespot in space 3 on the ventral hindwing (Figs. 2-4, 32-33), while all other species in the ignobilis-group generally have this spot fully developed. However, there is variation in this trait and occasional specimens of $B$. ignobilis may have a fully developed eyespot. Nevertheless it is a useful initial diagnostic tool before looking at more subtle characters, but not something to alone rely on for identification. The male can be identified by the presence of an extended comb of short shiny black hairs extending from space $1 \mathrm{c}$, in a direction towards the tornal point of the wing and partly covering a prominently enlarged section of vein $1 \mathrm{~b}$. The vein is enlarged for about one half to two-thirds of its total length starting from near the base of the wing, and the enlarged section is covered with modified beige scales clearly standing out from the darker colour of the wing (Fig. 6). There are no traces of androconial structures on the dorsal forewing. The female is harder to identify in cases where the eyespot in space 3 on the ventral hindwing is not missing, but in general the shape of the forewing apical band should be sufficient. Specimens from the eastern part of the range (Fig. 33) have vein 4 more heavily marked in dark, almost breaking up the apical patch in a similar way as in B. maesseni (Fig. 31) (see section on female identification below). However, the species are only co-occurring in West Africa, where B. ignobilis generally have a more solid apical patch (Fig. 32). It is therefore a quite reliable identification cue in the areas where the two species occur sympatrically. Across its entire range there is a clinal change in the wing pattern in both sexes of $B$. ignobilis. The main difference is a gradual change in the shape of the ventral hindwing discal band that gets a sharper angle at the distal end of the cell of both wings in an eastwards direction. Another less marked difference is a generally cleaner white and better-developed apical band in males from further east, western males tend to have faintly marked yellow white patch (Fig. 3). In addition, as stated above, the female band is often a little more broken up by vein 4 in the eastern parts of the range.

Supression of subspecific taxa. The rather strong geographic variation in the species was the basis for the descriptions of two additional subspecies. Specimens from between Liberia and western Nigeria were assigned to the nominate subspecies (Type locality: Ghana), while the name B. ignobilis eurini Condamin \& Fox 1963 was assigned to specimens between eastern Nigeria and DRC (Type locality: Lolodorf, Cameroon). The populations found in the extreme east of the range, mainly Uganda and Tanzania, were assigned the name B. ignobilis acutus Condamin 1965b (Type locality: Bwamba Forest, Uganda). However, Condamin (1973) later suggested that this difference might indeed be clinal, and it is likely that he saw more material of an intermediate morphology in the time between describing the subspecies in the first place up until writing his 1973 monograph. After investigating over 700 specimens from across the entire range of the species, without finding any area where a sharp transition between the previously described subspecies takes place, we hereby suppress eurini and acutus as valid names and consider $B$. ignobilis as a single taxon with a marked clinal variation.

Distribution. The species is distributed between Sierra Leone and Central Uganda, reaching the Lake Victoria forests in Eastern Tanzania. It extends further south than any other species in the ignobilis-group with a small number of records in southern DRC (Fig. 27-28).

Comments. The original description of the species (Butler 1870) does not mention anything regarding the male morphology, and it is likely that the single female individual in BMNH currently recognised as a type (Voucher ID: BMNH(E)1054533) was the only specimen available to Butler. Aurivillius appears to have made the first published description of B. ignobilis males. In his report (Aurivillius 1893) on material collected by Yngve Sjöstedt in Cameroon between 1890 and 1891, he clearly notes the black haircomb on the hindwing. Sjöstedt was 
reported to have collected two pairs of the species, and four matching specimens bearing labels with his name are still in the collections of NHRS. The types of Bicyclus ignobilis eurini were not studied (they are located in the Carnegie Museum in Pittsburgh, USA). However, the original publication (Condamin \& Fox 1963) has detailed photos of the holotype and allotype, and describes the main morphological characters in extensive detail. We did investigate several specimens from the same general location in Cameroon (Supplementary table 1).

\section{Bicyclus rileyi Condamin}

(Figs. 7-10, 29-30)

Bicyclus rileyi Condamin 1961 (Bitje, Ja River, Cameroon)

Bicyclus rileyi Condamin 1965a (Separate description of female neallotype)

Material studied. Type material. Holotype $\delta^{\top}$ : Cameroon, Bitje, Ja River, $\left(3^{\circ} 09^{\prime} \mathrm{N}, 13^{\circ} 00^{\prime} \mathrm{E}\right)$, G.L. Bates leg., BMNH(E) \#997642 (BMNH). Neallotype: ${ }_{\text {+ }}$ Same locality as holotype, iv-vi.1910, G.L. Bates leg., BMNH(E) \#997643 (BMNH).

None-type material. Cameroon: Dja River $\left(3^{\circ} 09^{\prime} \mathrm{N}, 13^{\circ} 00^{\prime} \mathrm{E}\right): 7 \widehat{\delta}^{\lambda}$. Ebogo $\left(3^{\circ} 23^{\prime} \mathrm{N}, 11^{\circ} 28^{\prime} \mathrm{E}\right): 7 \delta^{\lambda}, 8$ q.

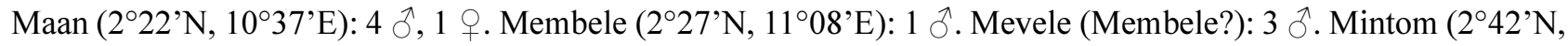

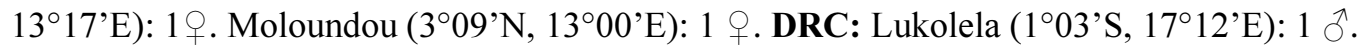

Diagnosis. The size alone sets this species well apart from all other morphologically similar looking taxa. The forewing length of the male holotype is $27 \mathrm{~mm}$ and the female allotype $31.5 \mathrm{~mm}$. The forewing measurements of males from the other species are usually in the region of $20 \mathrm{~mm}$ with females measuring just a few $\mathrm{mm}$ longer. The male androconial structures (Fig. 10) are somewhat intermediate compared to more distinctly different members in the species-group. There is a rather thick cover of shiny dark scales and hairs in most of the anal areas of the dorsal hindwing and a comb of dark hairs covering the base of vein 1 on the dorsal forewing. The banding pattern on the ventral side is highly irregular, and the forewing shape is more drawn out towards the apex in the male compared to any of the other species in the group (Fig. 7). The ventral eyespots follow a more even curve than in the other ignobilis-group members. The light pattern on the female dorsal surfaces is much enlarged, reaching well down under the eyespot in space 2 and continuing into space $1 \mathrm{~b}$ and 1a (Fig. 8). Just like the male, the female is very large compared to any of the other species in the group.

Distribution. Southern Cameroon and western DRC (Fig. 29). This species was previously only known from the type pair collected in Bitje, Cameroon in 1910, and described some 50 years later by Condamin $(1961 ; 1965)$. Since the beginning of the current century, collectors working for ABRI in Cameroon have found a further 34 specimens from a range of locations south of Sanaga River. In 2013 a single specimen was collected in Lukolela in DRC, suggesting an even larger range than previously reported (Brattström 2012). It has been suggested as likely to be present in Gabon, but despite extensive collection efforts in the country no specimens have yet been found (Vande weghe 2010). Given the small amount of collected material known in total for such a large conspicuous species, and mostly from areas where large collection efforts have recently been made, it is likely that the species is highly localised or has a behaviour making it likely to escape detection.

\section{Bicyclus maesseni Condamin}

(Figs. 11-14, 27, 31)

Bicyclus maesseni Condamin 1971 (Lipke Mate, Ghana)

Material studied. $79 ð \& 127$ q. See Supplementary Table 1.

Diagnosis. The male (Fig. 11) has two well defined androconial structures (apart from the normal brush in the hindwing cellular area) that set it apart from the other species in the group (Fig. 14). Just as in B. ignobilis a part of vein $1 \mathrm{~b}$ on the dorsal hindwing is enlarged, but in B. maesseni the enlarged part is much shorter and wider, forming a distinctive bulge close to the base of the wing. There are no long black hairs covering this structure (as found in B. ignobilis). There is also a quite distinct androconial structure located basally in space $1 \mathrm{~b}$, immediately above vein 1 , on the dorsal forewing. It is formed by a patch of scales being slightly lighter than the dark base colour, and the basal part of the patch is covered by a loose collection of short hairs. Both sexes (Figs. 11-12) also stand out 
from similar sympatric species by the heavily darkened veins crossing through the apical patch on the forewing, breaking the patch up in at least two or more separate light subunits.

\section{Bicyclus rileyi Condamin 1961}
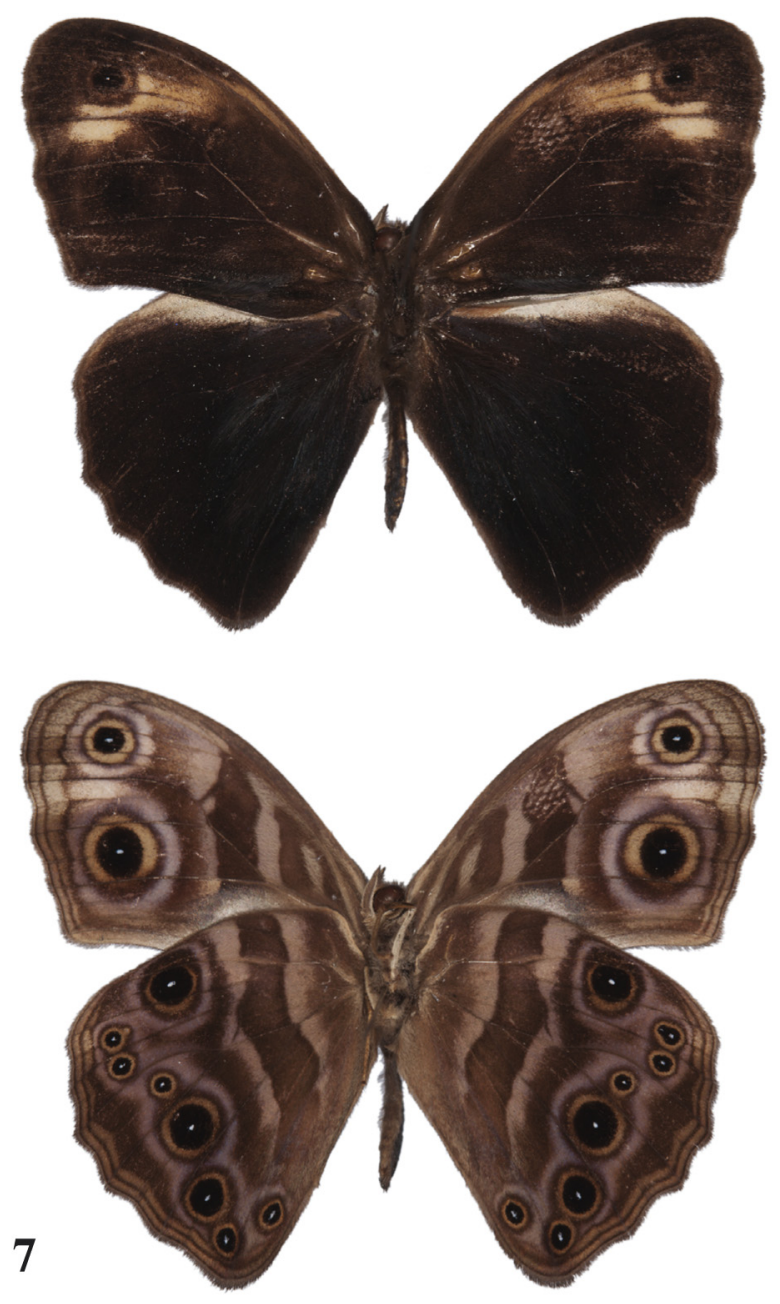

9
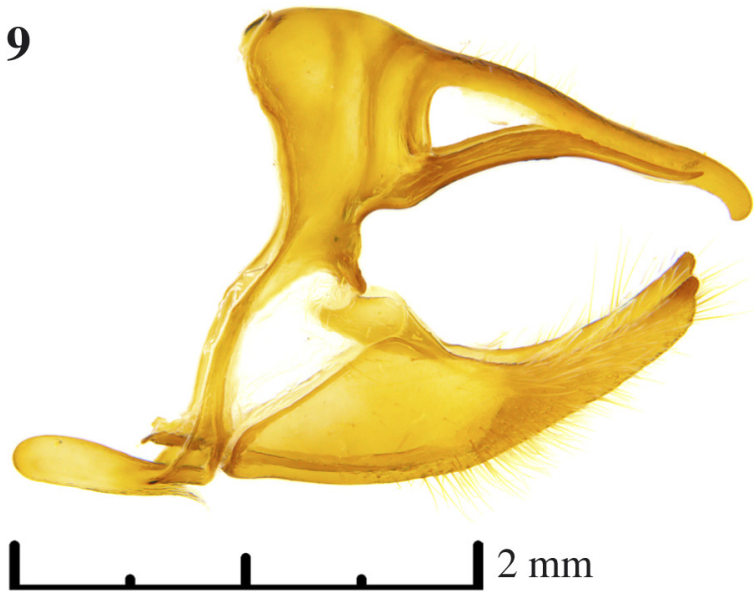

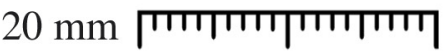
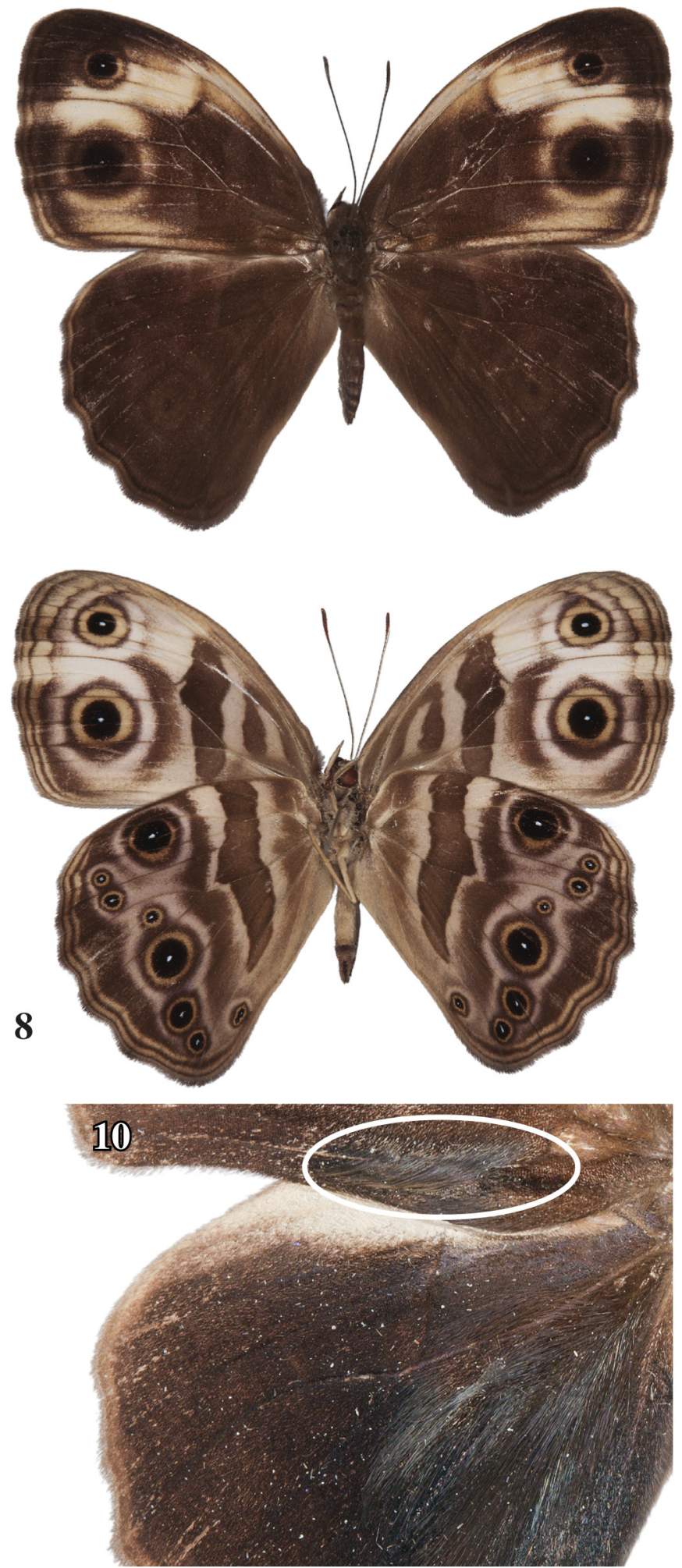

FIGURES 7-10. Bicyclus rileyi Condamin 1961. 7. Male, Cameroon (OB-ABRI-1021). 8. Female, Cameroon (KAP-ABRI12-578). 9. Male genitalia, Cameroon (OB-ABRI-0050). 10. Androconial structures (ABRI-14-657): There is a dark comb of hairs (but no brush like hair-pencil) in the basal area of space $1 \mathrm{~b}$ on the dorsal forewing (encircled in white). The anal area of the hindwing has a dense cover of dark shiny hairs and scales. The hindwing cell-brush is mainly covered by the forewing so that only the most basal parts are visible. 

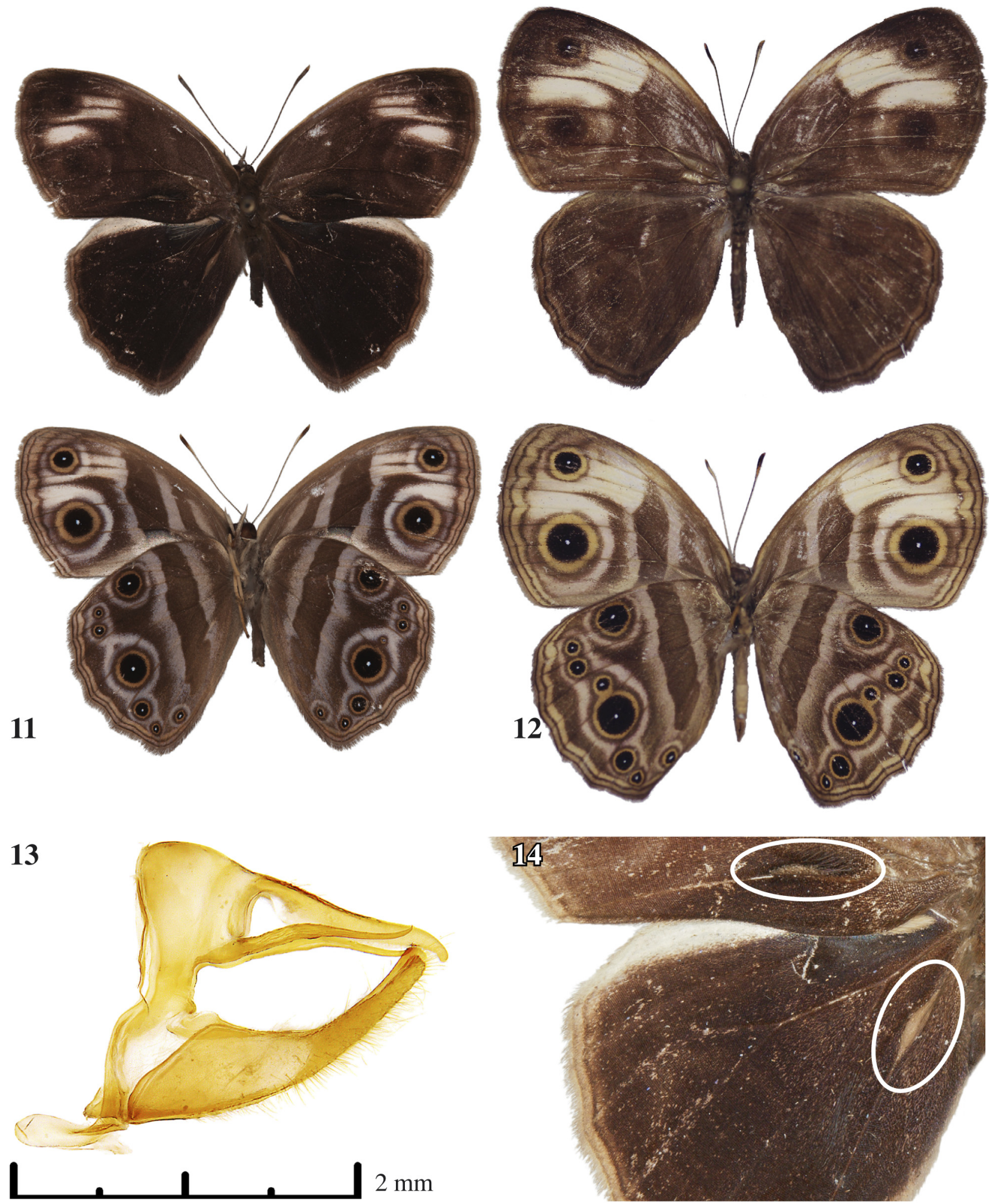

FIGURES 11-14. Bicyclus maesseni Condamin 1971. 11. Male, Ghana (OB-TER-0067). 12. Female, Ghana (ABRI-14-354). 13. Male genitalia, Ghana (OB-TER-0067). 14. Androconial structures (OB-TER-0067): There is a patch of androconial scales in the basal parts of space $1 \mathrm{~b}$ on the dorsal forewing covered by a loose comb of black hairs (encircled in white). The basal parts of vein $1 \mathrm{~b}$ on dorsal hindwing are enlarged into a small lightly coloured bulb, and this part of the vein is not covered by any long dark hairs. The enlarged part of the vein is shorter, but wider, than in B. ignobilis and usually very conspicuous (encircled in white). The basal parts of the hindwing cell-brush is also visible in the image. 
Distribution. West Africa between Sierra Leone and western Nigeria (Fig. 27). This species was previously thought to occur mainly in the Volta region in Ghana and in eastern Ivory Coast. However, a range of new records has recently been acquired from Liberia and Sierra Leone, as well as many more sites in Ghana, often in sympatry with B. ignobilis. Despite all of these new records B. maesseni is still the only representative of the group in the forests of the Volta region, where it can be reasonably common in the wetter areas. There is also a single specimen from Okomu in western Nigeria, collected by J. Wojtusiak in 1986 and kept in the MZUJ collections (T. Larsen \& T. Pyrcz Personal Communication). We have investigated detailed photos of this specimen and it is clearly a male of B. maesseni. At first this might appear improbable, but in reality most species that are found in Volta also extend their distribution eastwards across the Dahomey gap into Western Nigeria and often further onwards to the east (Larsen 2005). This suggests that the gap opened up well after most current western rainforest species was already dispersed on both sides of its current borders. It is therefore not impossible that the Okomu specimen is a representative from a small relict population in Western Nigeria. Okomu is one of the better-surveyed parts of this area so it is surprising that no other specimens have been previously found, but $B$. maesseni might just be incredibly rare east of the Volta region. As most forests in western Nigeria are now lost we might not be able to ever know if the species perhaps used to be more widespread until very recently.

Comments. We did not investigate the type material that is kept in MNHN, but the images in the original description (Condamin 1971) are very clear, leaving no doubt about the morphological characters defining the species.

\section{Bicyclus brakefieldi Brattström}

(Figs. 15-18, 29, 36)

Bicyclus brakefieldi Brattström 2012 (Medje, DRC)

Material studied. Type material. Holotype: ${ }^{\lambda}$, DRC, Orientale Province, Medje ( $\left.2^{\circ} 25^{`} \mathrm{~N}, 27^{\circ} 15^{\prime} \mathrm{E}\right)$, iv-vi.1910, Exp. Lang-Chapin leg., OB-TER-0108 (MRAC). Paratypes: đ̄, DRC, Equateur Province, Bamanya, 300 m.a.s.l. ( $0^{\circ} 01$ 'S, 18 20'E), 28.ix.1961, Rev. G. Hulstaert leg., OB-TER-0009 (MRAC). +, DRC, Orientale Province, Elisabetha, 400 m.a.s.l. $\left(1^{\circ} 14^{\prime} \mathrm{N}, 2^{\circ} 36^{\prime} \mathrm{E}\right)$, no date, Mme. Tinant leg., OB-TER-0110 (MRAC). +, DRC, Equateur Province, Eala $\left(0^{\circ} 05^{\prime} \mathrm{N}, 18^{\circ} 20^{\prime} \mathrm{E}\right)$, i.1936, Lieut. J. Ghesquière leg., OB-TER-0110 (MRAC), Misidentified paratype (belongs to B. ignobilis).

None-type material. DRC: Baliko/Basayo $\left(0^{\circ} 28^{\prime} \mathrm{N}, 25^{\circ} 24^{\prime} \mathrm{E}\right): 2 \partial^{\lambda}, 1{ }^{\circ}$. Cantine $\left(0^{\circ} 31^{\prime} \mathrm{N}, 29^{\circ} 12^{\prime} \mathrm{E}\right): 1 \mathrm{O}^{\lambda}$.

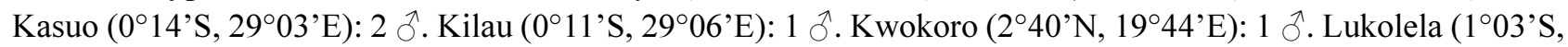

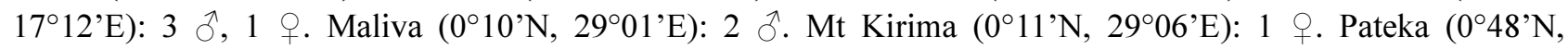
$\left.29^{\circ} 18^{\prime} \mathrm{E}\right): 3$ 今 3,1 \%.

Diagnosis. The lack of any brush in space $1 \mathrm{~b}$ on the dorsal forewing, and the absence of any markedly enlarged parts of vein $1 \mathrm{~b}$ on the hindwing, sets the male of this species apart from all of the other four small members of the species-group (Fig. 18). The hindwing is covered in shiny dark hairs in the anal area, making the males similar to $B$. rileyi, but the latter species is of a much larger size, and has more elongated and scalloped forewings clearly setting them apart from B. brakefieldi. The female of B. brakefieldi has a yellow-white apical patch with less well-defined borders than similar species (Fig. 16). Accurately separating the female from similar species remains one of the more challenging tasks when dealing with the ignobilis-group. However, now that our suggested pairing has been verified by our molecular phylogeny, we feel confident in our re-evaluation of the female morphology (see separate section about female morphology below).

Distribution. DRC from Lukolela to North Kivu, mainly found north of River Congo (Fig. 29). There is a set of three specimens belonging to the type series at MRAC, all from different collection sites across DRC. A further set of nineteen specimens has now been identified from recently collected material at ABRI, slightly widening the distribution to include the Kivu area. All known specimens are still from the northern parts of DRC, and the distribution is unlikely to extend beyond the western side of River Congo and Ubangi. B. brakefieldi is broadly sympatric with $B$. ignobilis throughout its range, and there is a small rather surprising overlap with $B$. rileyi as evidenced from a single specimen of the latter from Lukolela in western DRC. 

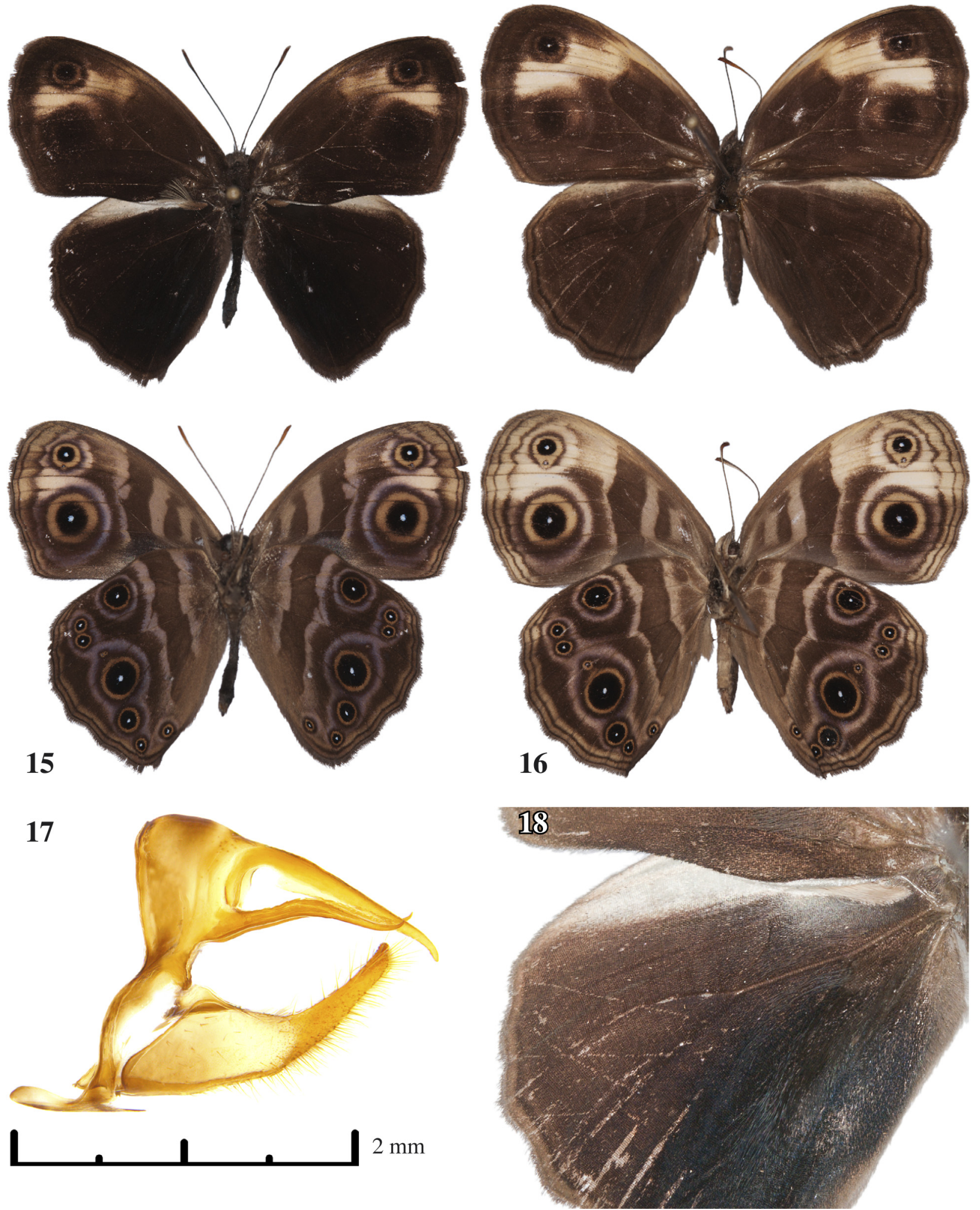

FIGURES 15-18. Bicyclus brakefieldi Brattström 2012. 15. Male, DRC (OB-ABRI-0024). 16. Female, DRC (OB-ABRI1016). 17. Male genitalia, DRC (OB-ABRI-0093). 18. Androconial structures (ABRI-14-657): There is no well-defined brush in the basal area of space $1 \mathrm{~b}$ on the dorsal forewing (present in B. ottossoni sp. nov. and B. vandeweghei $\mathrm{sp}$. nov.). The anal area of the hindwing is covered with dense shiny black hairs and the base colour is also darker in this region. Only the basal parts of the hindwing cell-brush is visible in the image as it is partly covered by the forewing. 

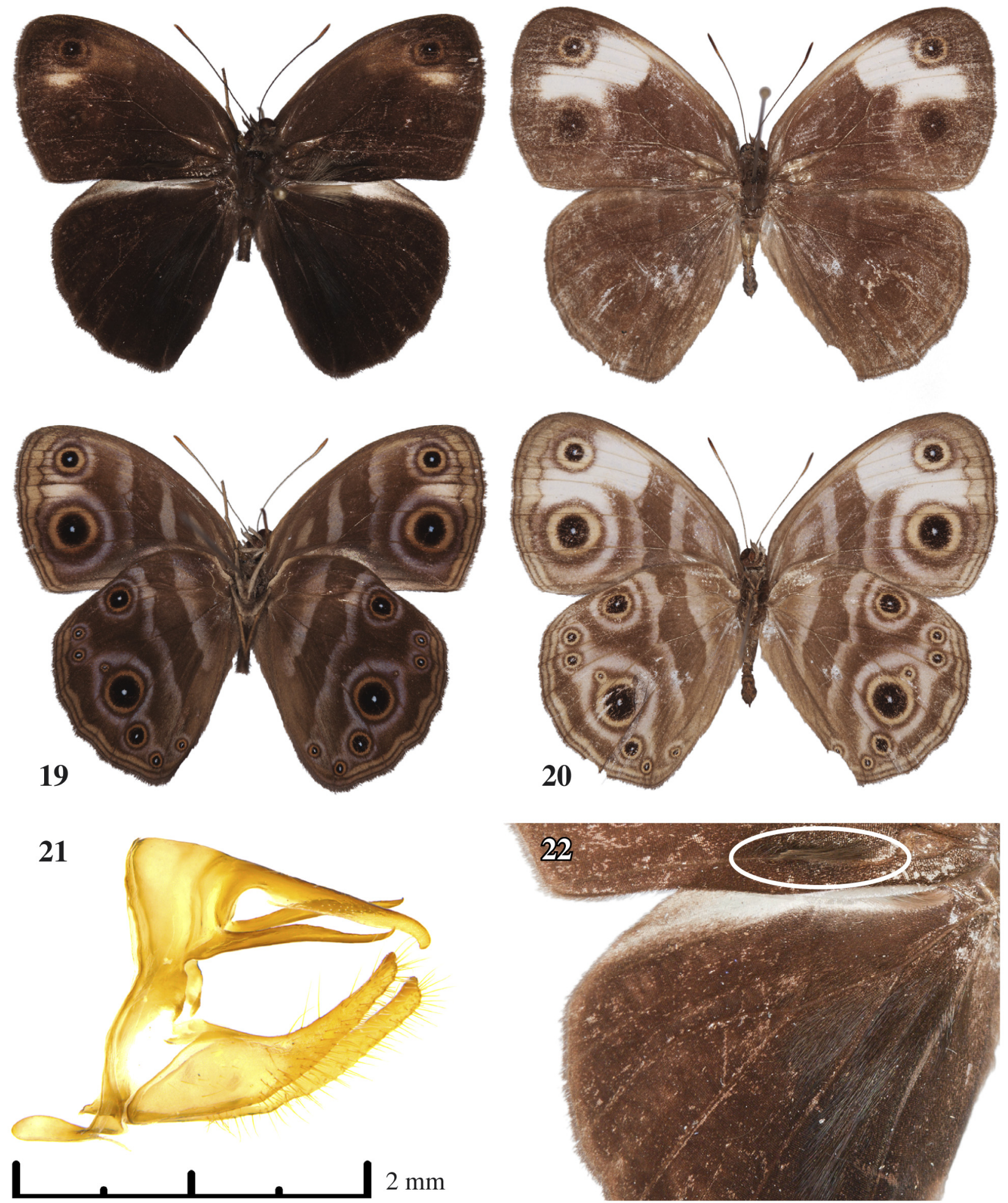

FIGURES 19-22. Bicyclus ottossoni Brattström sp. nov. 19. Male paratype, Cameroon (OB-ABRI-0077). 20. Female paratype, Cameroon (OB-ABRI-1013). 21. Male paratype genitalia, Cameroon (OB-ABRI-0077). 22. Androconial structures (OB-ABRI-0077). There is a well-defined brush (encircled in white) in the basal area of space $1 \mathrm{~b}$ on the dorsal forewing (also present in $B$. vandeweghei sp. nov.). The anal area is partly covered by dense dark brown to black hairs and vein $1 \mathrm{~b}$ is slightly enlarged from close to its base up to about half of its length. Only the basal part of the hindwing cell-brush is visible as it is mainly covered by the forewing. 
Comments. This species was originally described by Brattström (2012) based on a male holotype and three paratypes, one male and two females. With much more material available and a molecular phylogeny to verify our re-evaluation of the female morphology within the ignobilis-group, we are certain that one paratype of $B$. brakefieldi collected in Eala, DRC (OB-TER-0110), is actually a B. ignobilis.

\section{Bicyclus ottossoni Brattström, sp. nov.}

(Figs. 19-22, 29, 34)

Type material. Holotype: ${ }^{\top}$ : Nigeria, Edo State, Ologbo Forest $\left(06^{\circ} 01^{\prime} \mathrm{N}, 05^{\circ} 33^{\prime} \mathrm{E}\right)$, 1.iv.2009, O. Brattström leg., OB-IND-1072 (OBRES). Paratypes: Same location as holotype: 1 ð : 2.iv.2009, O. Brattström leg., OB-IND1077 (OBRES). 1 : 30.x.2008, O. Brattström leg., OB-IND-0025 (OBRES). 2 古: 10.iv.2010, O. Brattström leg., OB-CAM-0108 \& OB-IND-1432 (OBRES). 1 क: 16.xi.2010, O. Brattström leg., OB-CAM-0109 (OBRES). 1 O : 22.xi.2010, O. Brattström leg., OB-IND-1752 (OBRES). Cameroon: Dja $\left(3^{\circ} 09^{\prime} \mathrm{N}, 13^{\circ} 00^{\prime} \mathrm{E}\right)$ : 1 ㅇ, v.2014,

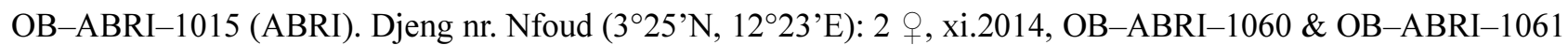

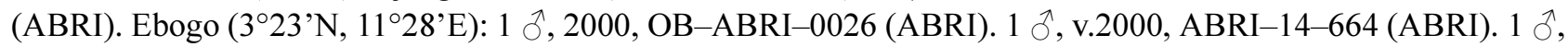
xi.2001, ABRI-14-663 (ABRI). Kiosi, S. Cameroon, Eq. Guinea Border (Exact location not identified): 1 , xi.2013, OB-ABRI-1014 (ABRI). Londji $\left(2^{\circ} 57^{\prime} \mathrm{N}, 09^{\circ} 57^{\prime} \mathrm{E}\right)$ : 1 ㅇ, i.1988, OB-ABRI-1013 (ABRI). Maan $\left(2^{\circ} 22^{`} \mathrm{~N}, 10^{\circ} 37^{\prime} \mathrm{E}\right): 10^{\uparrow}$, xi.2002, OB-ABRI-0023 (ABRI). 1 ô, xi.2004, OB-ABRI-0077 (ABRI). Mt. Mille $\left(3^{\circ} 17^{\prime} \mathrm{N}, 10^{\circ} 50^{\prime} \mathrm{E}\right): 1 \mathrm{O}^{\wedge}, \mathrm{v} .2011, \mathrm{OB}-\mathrm{ABRI}-0087$ (ABRI).

Male description. Forewing length 19-22 $\mathrm{mm}$ (Holotype $20 \mathrm{~mm}$ ). The ground colour of the dorsal surface is a uniformly dark brown with a warm hue (Fig. 19). The forewing has a well-developed apical eyespot with an orange outer ring and a white central spot. There is an off-white shading of the apical area of the wing in a basal and anterior direction from the eyespot, but it only forms a well-defined patch in a small area of space 3 below the eyespot. The hindwing has a shiny white costal area extending to the outer margin in space 6 , but with some darker scales mixed in close to the margin at the apex. The dorsal forewing has a well defined androconial brush placed basally in space $1 \mathrm{~b}$ just above vein 1 . The brush is about $4 \mathrm{~mm}$ long, and the hairs are of the same colour as the wing, and aligned along vein 1 pointing towards the margin (Fig. 22). The hindwing has a hair brush originating from close to the base of the cell, the brush is light beige at the base and gradually fades into a pale white yellow at the tip. It covers a patch of light yellow androconial scales located in a small pit where the base of vein 7 originates from the discocellular vein. Vein $1 b$ is slightly enlarged at the middle of its length, with a small collection of hairs located at the base of spaces $1 \mathrm{~b}$ and $1 \mathrm{c}$ covering the basal part of the enlarged section of the vein. There is a concentration of shiny dark short hairs in space 1c extending from the base to about two thirds of the length of the space, and a similar covering of hairs at the base of space 2 and the lower part of the discocellular area. In worn specimens these hairs are often missing, or appear to be arranged in small patches.

The ventral surface base colour is a similar dark warm brown with two beige-purple bands extending across both wings so that a discal band of the ground colour is formed between them (Fig. 19). On the forewing there is an additional light band placed basally in the wing cell angled slightly towards the apex. The basal edge of the main inner light band, and the distal marginal edge of the outer band, gradually fade into the ground colour. The bands are fairly straight across both wings, but with a somewhat wavy outline. At the end of the cell of each wing the light outer band encroaches slightly into the cellular space. All eyespots on the ventral side are surrounded by a light halo of a similar colour to the light bands. This halo turns almost white immediately under the forewing apical patch. The ventral forewing has two well-developed eyespots with yellow-orange outer rings. The hindwing has a row of eight similar eyespots from space $1 \mathrm{~b}$ up to space 6 (there are two spots in space 1c). All ventral eyespots have white central spots. The eyespot in space 2 is always the largest and the spot in space 3 is variable in size, but usually well developed, especially in specimens from Nigeria. The line of spots follows the outer margin except in spaces 2 and 3 where the spots are shifted inwards. The outer margin of the forewing is less convex than in similar species.

Female description: Forewing length $22-24 \mathrm{~mm}$. The ground colour is variable between specimens, but in general it is of a somewhat warm chocolate brown hue with a well-marked off-white apical patch on the dorsal forewing (Fig. 20). This patch is small for the group, but its margin is unusually well defined, almost appearing like two joined rectangles. The inner angle at vein 4 is especially sharp, with minimal dark colouration along the vein breaking up the band (Fig. 34). There is a well-developed apical eyespot with an orange-yellow outer ring and a 
white central spot. The apical patch is separated from the patch by a thin dark margin that neatly follows the shape of the eyespot. There is sometimes a small spot below the apical spot, but this is of no diagnostic value and occurs occasionally in all species in the group. There is a minute white spot on the dorsal forewing in space 2 marking the centre of the eyespot that is fully developed immediately beneath on the ventral side. This is not normally seen in females of the other species. The dorsal hindwing is unmarked apart from a slightly lighter costal area. The ventral pattern is vaguely seen through to the dorsal surface. The ventral side is typical for the group and similar to the male, except being a bit lighter and with a more uneven discal band on the distal edge of the hindwing. The lighter areas immediately outside the band enters the wing cells in the distal edge on both fore- and hindwings. Just as in the male, the other margin of the forewing is less convex than in similar species.

Diagnosis. Males of $B$. ottossoni differ from all other members of the ignobilis-group by the combination of a clear hair brush in space $1 \mathrm{~b}$ of the forewing together with a minute apical patch on the forewing (Fig. 19). The females are harder to separate from similar species, but the clearly defined apical patch and more squared forewing shape are diagnostic (Fig. 20). The species is verified as a separate unit by the molecular phylogeny. Further details regarding accurate identification of female specimens from the ignobilis-group is found below.

Distribution. The species has a surprisingly discontinuous distribution with a single known Nigerian location in the western Niger Delta (Ologbo), combined with records from a handful of locations in southern Cameroon (all south of Sanaga River) (Fig. 29). The habitat in Cameroon is unknown, but the Nigerian specimens were all collected in a wet swampy rainforest at the edge of the Niger Delta. They were all spotted in shady areas of the forest flying close to the ground. It is likely that the species is present in many more Nigerian sites, but there is limited historic material available and the area is under-surveyed. Without better evidence of true absence from the Eastern Nigerian and Western Cameroonian coastal areas we see no reason at this point to split the populations into subspecies, even if there are small morphological differences, mainly with regards to the eyespot in space 3 on the ventral hindwing being larger in Nigerian specimens.

Etymology. The species is named in honour of Ulf Ottosson. Without his encouragement, generosity and enthusiasm for African fieldwork it is unlikely the first author would ever have set his foot in Nigeria and later embarked on his current research.

Comments. The holotype and some Nigerian paratypes were caught in 2009 during fieldwork for a study of sex pheromones in Bicyclus (Bacquet, Brattström et al. 2015). Due to the way sampling for this project was carried out they have had their wings removed from the thorax and one side of the wings has been dissected and used for pheromone analyses. The remaining parts of each specimen are now stored as forewing and hindwing from the one side kept in an envelope, while the bodies are kept separately in vials containing $99 \%$ ethanol. All individuals with codes beginning with 'OB-IND-'have been sampled and stored in this way.

\section{Bicyclus vandeweghei Brattström, sp. nov.}

(Figs. 23-26, 29, 35)

Material studied. Type material. Holotype: ${ }^{\top}$, Gabon, Bakouaka $\left(00^{\circ} 08^{\prime} \mathrm{N}, 13^{\circ} 39^{\prime} \mathrm{E}\right), 16 . x i 1.2007$, G. Vande weghe leg., OB-ABRI-0068 (ABRI). Paratype: ㅇ, Republic of Congo, Kelle $\left(00^{\circ} 08^{\prime} \mathrm{N}, 13^{\circ} 39^{\prime} \mathrm{E}\right)$, i.1993, S. Collins leg., OB-ABRI-0140 (ABRI).

Male description. Holotype forewing length $23 \mathrm{~mm}$. The dorsal surface ground colour is a warm dark brown, gradually turning into a slightly darker hue towards the distal parts of the hindwings (Fig. 23). The dorsal forewing has a quite large, but vague eyespot with an orange-brown outer ring and a tiny white central spot. There is a yellow-beige apical patch formed of a triangular patch in space 3 and 4 below the eyespot, merging with an hourglass shaped patch in spaces 4 and 5 . Even if broken up by a darker vein above the cell, the patch extends faintly along the mid costal margin towards the wing base for a few millimetres, before fading into the ground colour. There is a sparse brush of hairs (about $3-4 \mathrm{~mm}$ long) located basally in space $1 \mathrm{~b}$, directly above vein 1 , extending towards the wing margin (Fig. 26). The hairs are similar in colour to the wings, and without good contrasting light are very hard to see clearly. There are no specialised androconial scales under the area covered by the hairs forming the brush.

The hindwing has a hair brush placed close to the base of the cell, the brush is light beige at the base and gradually fades into a pale white yellow at the tip. It is covering a pit at the base of vein 7 , at the point where it 
meets the discocellular vein. Due to the way the specimen is set we do not know the structure of the patch, but it is likely that it contain small yellow to white scales like the rest of the members of the ignobilis-group. The costal area of the hindwing is covered in light scales down to the area in space 6 just above vein 6 . There is a small amount of dark hairs in space $1 \mathrm{c}$ and $1 \mathrm{~b}$ in the basal part of the wing. Vein $1 \mathrm{~b}$ is at most lightly inflated a few millimetres away from its base, and this part of the vein is lightly covered in darker hairs.

The ventral surface base colour is similar to the dorsal side, but with a more violet tone (Fig. 23). There are two beige-purple bands extending across both wings so that a discal band of the ground colour is formed between them. On the forewing there are two additional light bands placed basally in the wing cell angled slightly towards the apex. The basal edge of the main inner light band and the distal marginal edge of the outer band gradually fade into the ground colour. The band is quite jagged on both sides and at the end of the cell on both wings there is a thin tooth like projection pointing downwards towards the mid margin. All eyespots on the ventral side are surrounded by a light halo of a similar colour to the light bands. This halo turns almost white immediately under the forewing apical patch. The ventral forewing has two well-developed eyespots with yellow-orange outer rings. The hindwing has a row of eight similar eyespots from space $1 \mathrm{~b}$ up to space 6 (there are two spots in space 1c). The eyespot in space 2 is the largest and the spot in space 3 is very small.

Female description: Paratype forewing length $24.5 \mathrm{~mm}$. The single female specimen (Fig. 24) is rather worn, and therefore the colour is hard to accurately describe. It is most likely of a similar medium dark brown as other females in the ignobilis-group. The apical patch on the dorsal forewing is better developed than in the male and of an almost pure white colour. The apical eyespot is also much better developed with a more clearly visible yellow outer ring. The central white spot is very small. The spot in space 2 , which is well developed on the ventral side, is marked on the dorsal side by dark shading, but without a white centre or any outer light ring. The hindwing is uniformly brown, except the costal area which is lighter close to the base of the wing. The hindwings of the paratype are quite damaged, but the margin appears to be somewhat concave at the point of space 2. It is possible that the intact wings would have had a slightly tailed appearance, with a more drawn out tonus compared to similar species. The ventral side is typical for the group and similar to the male, except being much lighter. The light outlines to the discal band and the halo around the eyespots are almost pure white. The light halo around the hindwing eyespots is very much broader than in the other known species in the group.

Diagnosis. $B$. vandeweghei is very similar to $B$. brakefieldi with the main character differences in their androconial arrangement. $B$. vandeweghei has a small hairpencil located basally in space $1 \mathrm{~b}$ of the dorsal forewing, with hairs pointing in the direction of the wing margin (Fig. 26). This type of androconial structure is not present in B. brakefieldi (Fig. 18). However, a similar kind of brush (although better developed) is present in Bicyclus ottossoni (Fig. 22), but the apical patch on the dorsal forewing is much smaller in this species. The female of $B$. vandeweghei is much harder to separate from $B$. brakefieldi. The paratype female of $B$. vandeweghei has a much more extensive diffuse light area around the eyespots on the ventral hindwing, and this character is probably sufficient to separate the females of these two species. We have not been able to investigate this trait in all specimens of the ignobilis-group, but no images, that we have available, of males and females from any other species show this trait. The holotype DNA has been sequenced, and it is distinctly different from all the other species in the group. The female paratype was separated by comparing the morphology of all the available specimens from the general geographic region of the collection site for the male holotype.

Distribution. The only two known records are from a small area in eastern Gabon and western Republic of Congo (Fig. 29).

Etymology. This species is named after Gaël Ruboneka Vande weghe, who collected the holotype during fieldwork related to his impressive book about Gabon butterflies (Vande weghe 2010).

Comments. A large amount of material from Gabon was collected by Vande weghe during the fieldwork leading up to his book on Gabon butterflies (2010). We have seen very little material of the ignobilis-group from the region, and it is likely that some of the records listed in the above mentioned book belong to $B$. vandeweghei. Investigating Vande weghe's reference collection would be of very high value to further work on many speciesgroups. 

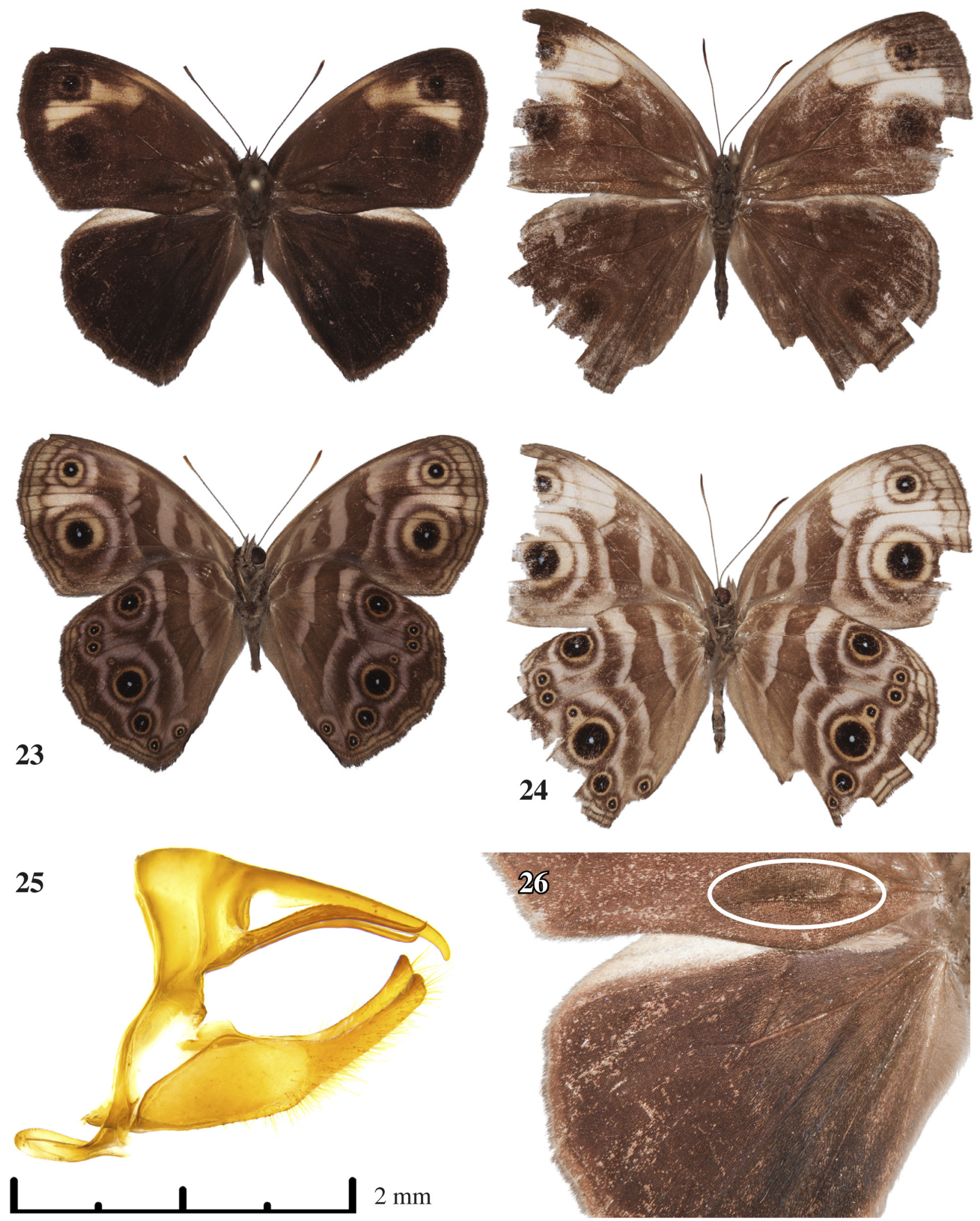

FIGURES 23-26. Bicyclus vandeweghei Brattström sp. nov. 23. Male holotype, Gabon (OB-ABRI-0068). 24. Female paratype, Republic of Congo (OB-ABRI-0143). 25. Male holotype genitalia, Gabon (OB-ABRI-0068). 26. Androconial structures (OBABRI-0068): There is a small inconspicuous brush (encircled in white) in the basal area of space $1 \mathrm{~b}$ on the dorsal forewing (also present in B. ottossoni sp. nov.). The anal area is lightly covered in dark brown hairs and vein $1 \mathrm{~b}$ is only enlarged for a very small part of its length. Only the basal parts of the hindwing cell-brush is visible in this image as it is mainly covered by the forewing. 


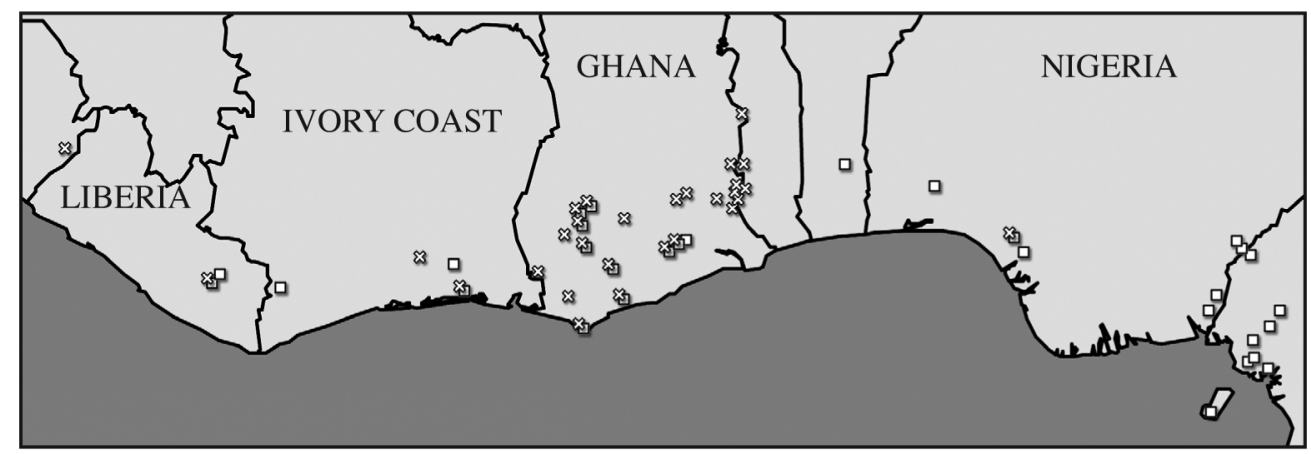

28

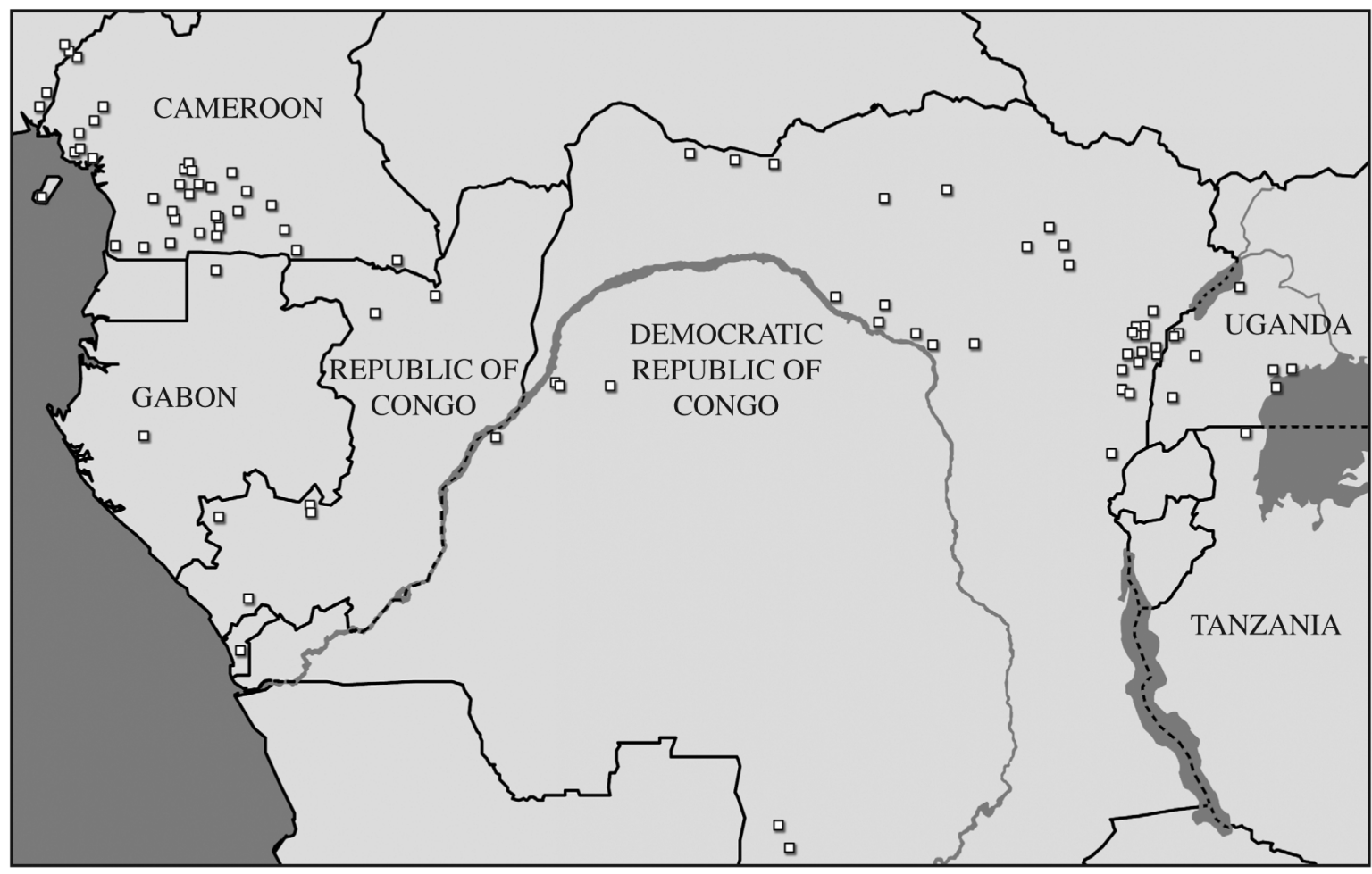

29

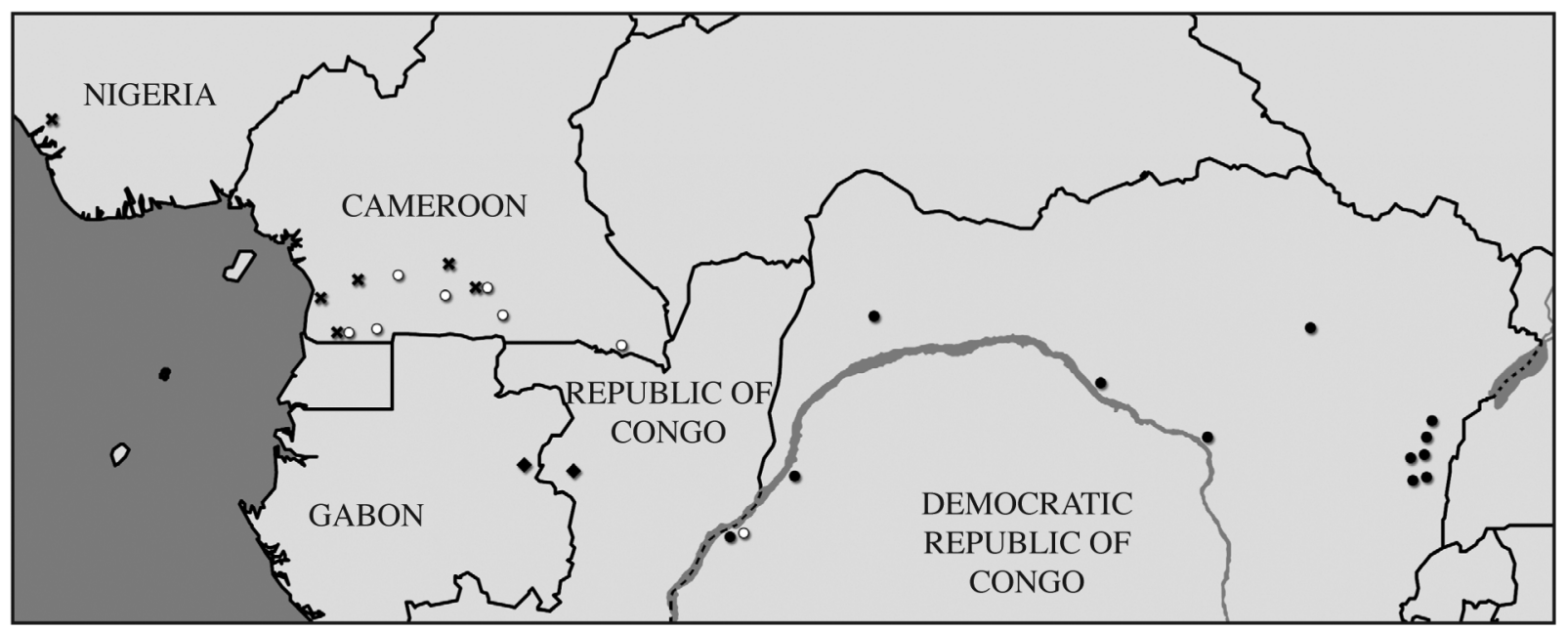

FIGURES 27-29. Distribution maps for the Bicyclus ignobilis species-group. Records of different species from the same site have been slightly offset when presented in the same map so that all species symbols can be clearly seen. Multiple records close to each other have been collapsed to a single point. The complete distributional data is available in Supplementary Table 1.2728. B. ignobilis (Open Squares) and B. maesseni (Open Crosses). 27. West Africa up to the Cameroonian border. 28. Cameroonian border and eastwards. 29. Remaining species occurring between Nigeria and Eastern DRC: B. brakefieldi (Filled Circles). B. ottossoni (Filled Crosses). B. rileyi (Open Circles). B. vandeweghei (Filled Diamonds). 

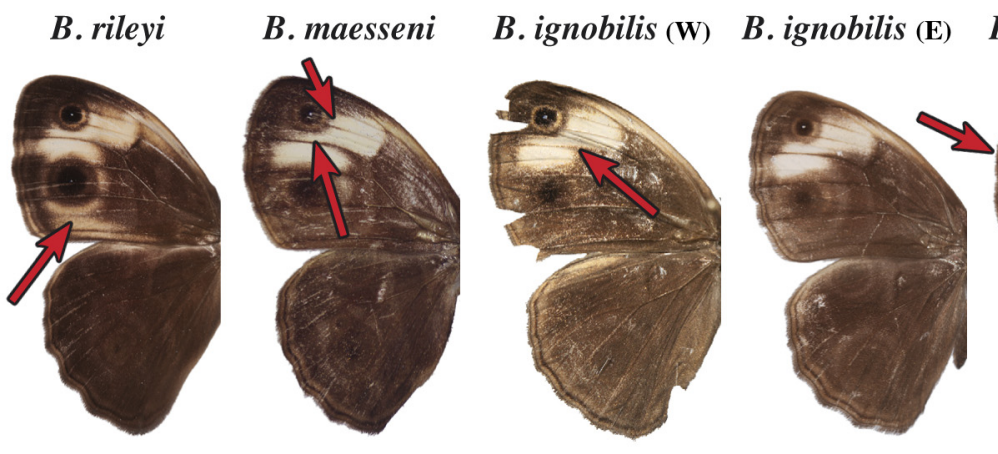

B. ottossoni

B. vandeweghei

\section{B. brakefieldi}

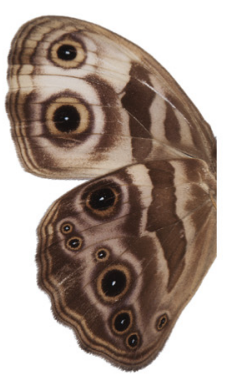

30

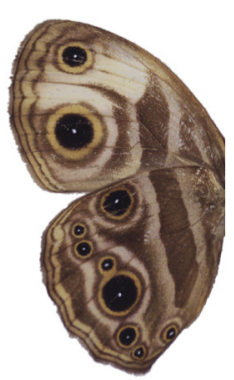

31

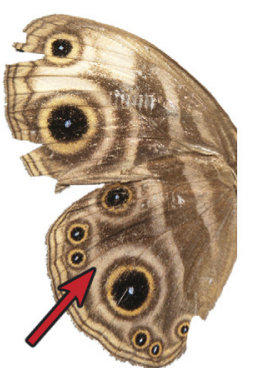

32

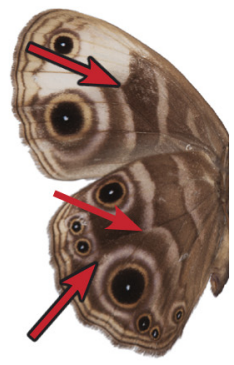

33
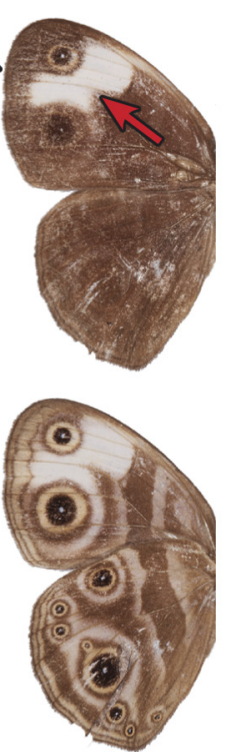

34
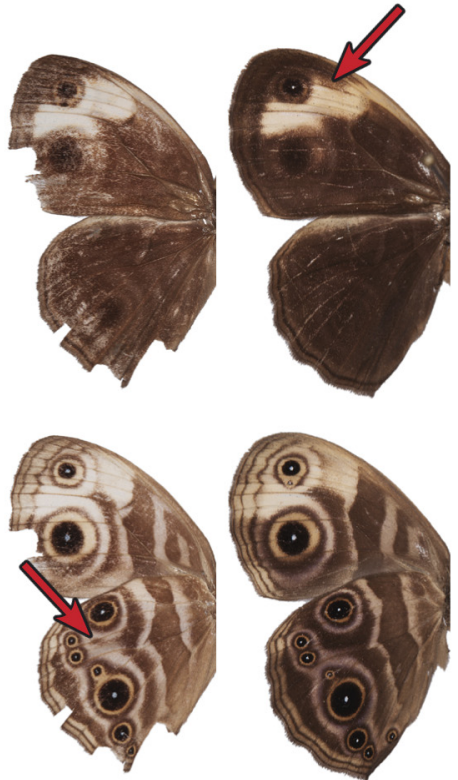

35

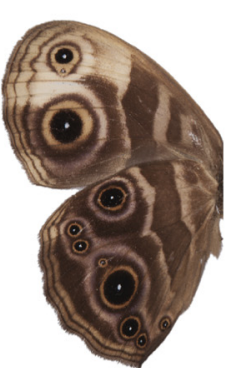

36

FIGURES 30-36. Identification of females from the ignobilis-group. The images are not shown to scale, arrows indicate the main characters of importance for identification. 30. B. rileyi is much larger than any other species and the light markings in the apical patch continue below the eyespot in space 2, and often reach the lower margin of the wing. 31. B. maesseni has the edge of the apical patch more broken up in the area closest to the apical eyespot. Also, vein 4 is heavily marked with darker scales, breaking up the patch along its entire length. 32. B. ignobilis (western part of range) almost always lack the ventral hindwing spot in space 3, the apical patch is also much more solid than in B. maesseni with vein 4 just making a dark indentation in the basal part of the light patch. 33. B. ignobilis (eastern part of range) has vein 4 more heavily darkened so that the apical patch is sometimes fully broken up in sections. This makes them appear similar to B. maesseni, but the latter species is not sympatric in the eastern part of the range of B. ignobilis. The ventral discal band gradually gets a more pronounced edge at the end of the cell on both wings in a clinal fashion towards the east of the species range. 34. In B. ottossoni the basal part of the apical patch lacks indentations of dark scales along vein 4 . The outer borders of the patch are much better defined than in the other species. The distal margin of the forewing is also much less convex, giving the wing a more squared shape. 35 . B. vandeweghei have much more prominent light shading around the hindwing eyespots. The apical patch is otherwise similar to B. ignobilis. 36 . B. brakefieldi have a more yellowish colour in the apical patch, and the part of the patch being placed basally of the eyespot is a bit fainter than in other species.

\section{Concluding remarks}

Identification of females. Whilst most male specimens should be straightforward to identify by the distinct androconial differences, females can still pose serious difficulties. This section summarises the main useful characters to facilitate correct identifications.

B. rileyi (Fig. 30) is comparably easy to identify as it is much larger, and also has a much more extensive, but quite undefined, apical patch. It would actually be more likely to make misidentifications between $B$. rileyi females and the large species in the evadne-group (Condamin 1973): B. alboplaga (Rebel), B. howarti Condamin, B. xeneas (Hewitson) and B. xeneodies Condamin. However, the row of ventral eyespots between spaces $1 \mathrm{c}$ and 5 on the hindwing is much more even in the latter four species compared to B. rileyi. The species in the evadne-group also always lack the eyespot in space $1 \mathrm{~b}$ that is found in all members of the ignobilis-group.

For the remaining five species the first character to investigate is the eyespot on the ventral hindwing in space 3. This spot is almost always missing in B. ignobilis (Fig. 32-33), and we know of no specimens of the other five species that completely lacks it. However, the spot is still occurring (sometimes being quite large) in a fair proportion of $B$. ignobilis females. This means absence is a reliable cue for identification, but presence cannot be used alone to single out some specimens of $B$. ignobilis from the four remaining species. 
In West Africa, from Sierra Leone up to and including Ghana, only B. ignobilis and B. maesseni occur, but they are often found in sympatry. In this region the apical patch is a reliable character; $B$. maesseni always has vein 4 covered in darker scales of the wings base colour and where it transects the patch it breaks it up in separated subpatches (Fig. 31). Vein 5 is also frequently as dark, further breaking up the patch. In B. ignobilis vein 4 is mainly darkened at the basal area that crosses over the basal parts patch making a small dark indentation (Fig. 32), but without fully separating the patch. Further east, the patch in B. ignobilis is gradually more broken up by vein 4 getting darker (Fig. 33), and specimens looking similar to B. maesseni start to appear. However, B. maesseni is fully absent from this area, almost certainly ending its distribution at the west side of the Niger delta.

B. ottossoni (Fig. 34) can be separated from any other species by the much more distinct border of its apical patch. Compared to all other species in the group the margin of the light patch is well defined, and at the point where it meets vein 4 on its basal side the white border forms a sharp almost $90^{\circ}$ angle without any clear indentation of dark scales. In addition, the outer margin of the forewing is much less convex than in the other species, giving the wing a more squared shape. Given the known distribution this species should only be possible to confuse with $B$. ignobilis and possibly $B$. maesseni.

The remaining two species present the most difficult identification issues. From B. vandeweghei (Fig. 35) we only know of a single female specimen, described as paratype based on morphology alone. Given the risk of an erroneous assignment it is therefore possible that the characters setting this specimen apart from other species could be due to an extreme variation in a misidentified specimen of a related species. The light colouring around the ventral eyespots on the hindwing are much broader than that which is normally found in the other species, a character also shared by the male holotype. The hindwing also appear to be a bit more drawn out to a tail towards the tornus, but the wings of the paratype are quite damaged so this might in reality be an artefact without diagnostic value. The apical patch looks similar to B. ignobilis, so it is not impossible, but very unlikely, that the female paratype of $B$. vandeweghei is an aberrant female of $B$. ignobilis.

B. brakefieldi (Fig. 36) has a distinctly more yellow-white apical patch and the section of the patch immediately basal to the apical eyespot (in space 4 and 5) is usually more faint and often shaped like a tilted hourglass. It can sometimes be very hard to distinguish between certain specimens of $B$. brakefieldi and $B$. ignobilis in cases where the $B$. ignobilis specimens have an eyespot in space 3 of the ventral hindwing. In these cases $B$. ignobilis should normally have more of space 6 occupied by the apical patch, as well as vein 4 more heavily darkened so that the patch is more broken up than in B. brakefieldi. The patch should also be of a more pure white colour in B. ignobilis.

Naturally, as the known ranges of all species except $B$. ignobilis are quite restricted, capture locations are very important to take into consideration. However, as four of the species in the group are rare in any collection, and likely to be highly localised in nature, eventually finding new records, far away from the currently known range, is quite likely.

Female bias in collections. The observed bias towards more females collected in B. ignobilis (63\%) and $B$. maesseni $(62 \%)$ is probably due to the less conspicuous colour of the males combined with the sedentary lifestyle of the members of the species-group. None of the species are frequently caught in fruit-baited traps, and tend only to be seen when startled from their resting places in thick undergrowth in wet forest. In this dark environment the sombre coloured males are much harder to spot, while the more conspicuous apical patches of the females make them much more visible in flight.

Relative abundance. Throughout most of the African rainforest (except the west parts of West Africa) $B$. ignobilis appears to be the most common member of the species-group. Within the known range of $B$. brakefieldi collections contains about twelve times the number of B. ignobilis (267/22). For B. ottossoni the figure is even higher with some twenty times higher numbers of $B$. ignobilis $(351 / 18)$. This could possibly be a result of behavioural differences making $B$. ignobilis more likely to be caught, but it is also likely that all species except $B$. ignobilis have far more specific habitat requirements and that their distributions are more fragmented.

\section{Acknowledgments}

Blanca Huertas (BNHM), Ugo Dall'Asta, Alice-Marie Busset and Jurate de Prins (MRAC), Martin Lödl and Sabine Gaal (NHMW), Tobias Malm (NHRS), kindly gave us access to, and assistance while working in, the museum collections. Teresa Di Micco de Santo assisted in the investigation of the material kept at ABRI. Freerk 
Molleman and Szabolcs Sáfián provided specimens for the molecular analysis. Michel Libert shared his database of sample locations across Africa. Torben B. Larsen informed us of the unexpected record of B. maesseni from Nigeria and provided photographs. Tomasz Pyrcz later located the same specimen and verified the capture location and data as well as dissected and photographed the genitalia. We would also like to thank all the people that collected the material now deposited in the investigated museum collections. Elishia Harji assisted with proofreading and language editing. Torben Larsen passed away during the writing of this manuscript. He was always incredibly supportive of our work and commented on many earlier manuscripts, his wealth of knowledge of African butterflies and his generous nature will always be missed. This project was financially supported by an ERC grant no 250325 (EMARES) to Paul M. Brakefield. Oskar Brattström's fieldwork was mainly funded through grants from the Wenner-Gren Foundation and the Helge Ax:son Johnson's Foundation.

\section{References}

Aduse-Poku, K., Brattström, O., Kodandaramaiah, U., Lees, D.C., Brakefield, P.M. \& Wahlberg, N. (2015) Systematics and historical biogeography of the Old World butterfly subtribe Mycalesina (Lepidoptera: Nymphalidae: Satyrinae). BMC Evolutionary Biology, 15, 167. http://dx.doi.org/10.1186/s12862-015-0449-3

Aurivillius, P.O.C. (1893) Beiträge zur kenntniss der Insektenfauna von Kamerun. 2. Tagfalter. Entomologisk Tidskrift, 14, 257-290. [in German]

Bacquet, P.M.B., Brattström, O., Wang, H-L., Allen, C.E., Löfstedt, C., Brakefield, P.M. \& Nieberding, C.M. (2015) Selection on male sex pheromone composition contributes to butterfly reproductive isolation. Proceedings of the Royal Society B, $282,20142734$. http://dx.doi.org/10.1098/rspb.2014.2734

Brakefield, P.M. \& Frankino, W.A. (2009) Polyphenisms in Lepidoptera: Multidisciplinary approaches to studies of evolution. In: Ananthakrishnan, N. \& Whitman, D.W. (Eds.) Phenotypic plasticity in insects. Mechanisms and consequences. Science Publishers, Inc., Plymouth, pp. 121-152.

Brattström, O. (2012) Bicyclus brakefieldi (Nymphalidae, Satyrinae), a new species of Bicyclus from the Congo River basin. Tropical Lepidoptera, 22, 62-65.

Butler, A.G. (1870) On Butterflies recently received by Mr. Swanzy from West Africa. Transactions of the Entomological Society of London, 123-124. http://dx.doi.org/10.1111/j.1365-2311.1870.tb01867.x

Condamin, M. (1961) Mises au point de synonymie et descriptions de nouveaux Bicyclus (Lepidoptera Satyridae). Bulletin de l'I.F.A.N, Series A, 23 (3), 782-799. [in French]

Condamin, M. (1965a) Mises au point et descriptions de nouveaux Bicyclus [Lepidoptera Satyridae]. Bulletin de l'I.F.A.N, Series A, 27 (3), 1095-1110. [in French]

Condamin, M. (1965b) Mises au point de synonymie et descriptions de nouveaux Bicyclus [Lepidoptera Satyridae]. Bulletin de l'I.F.A.N, Series A, 27 (4), 1439-1448. [in French]

Condamin, M. (1971) Descriptions de nouveaux Bicyclus [Lepidoptera Satyridae] et mises au point de synonymie. Bulletin de l'I.F.A.N, Series A, 32 (4), 1068-1077. [in French; Delayed publication of 1970 volume year]

Condamin, M. (1973) Monographie du genre Bicyclus (Lepidoptera Satyridae). Ifan-Dakar, Dakar, 324 pp. [in French]

Condamin, M. \& Fox, R.M. (1963) A new subspecies of Bicyclus ignobilis [Lepidoptera Satyridae]. Bulletin de l'I.F.A.N, Series A, 25 (4), 1166-1167.

Drummond, A.J. \& Rambaut, A. (2007) BEAST: Bayesian evolutionary analysis by sampling trees. BMC Evolutionary Biology, 7, 214. http://dx.doi.org/10.1186/1471-2148-7-214

Hall, T.A. (1999) BioEdit: a user-friendly biological sequence alignment editor and analysis program for Windows 95/98/NT. Nycleic Acids Symposium, Series 41, 95-98.

Kirby, W.F. (1871) A Synonymic Catalogue of Diurnal Lepidoptera. John van Voorst, London, 690 pp. http://dx.doi.org/10.5962/bhl.title.23779

Larsen, T.B. (2005) Butterflies of West Africa. Apollo Books, Stenstrup, 865 pp.

Miller, L.D. (1970). Nomenclature of wing veins and cells. Journal of Research on the Lepidoptera, 8, 37-48. [delayed publication of 1969 volume year]

Monteiro, A. \& Pierce, N.E. (2001) Phylogeny of Bicyclus (Lepidoptera: Nymphalidae) Inferred from COI, COII, and EF-1a Gene Sequences. Molecular Phylogenetics and Evolution, 18, 264-281. http://dx.doi.org/10.1006/mpev.2000.0872

Reuter, E.R. (1896) Über die Palpen der Rhopaloceren: ein Beitrag zur Erkenntnis der verwandtschaftlichen Beziehungen unter den Tagfaltern. Acta Societas Scientiarum Fennica, 22, 1-577. [in German] 
Stamatakis, A. (2006) RAxML-VI-HPC: maximum likelihood-based phylogenetic analyses with thousands of taxa and mixed models. Bioinformatics, 22, 2688-2690.

http://dx.doi.org/10.1093/bioinformatics/btl446

Vande weghe, G. (2010) Les papillons du Gabon. Wildlife Conservation Society, Libreville, 426 pp. [in French]

Wahlberg, N. \& Wheat, C.W. (2008) Genomic outposts serve the phylogenomic pioneers: designing novel nuclear markers for genomic DNA extractions of Lepidoptera. Systematic Biology, 57, 231-242.

http://dx.doi.org/10.1080/10635150802033006 